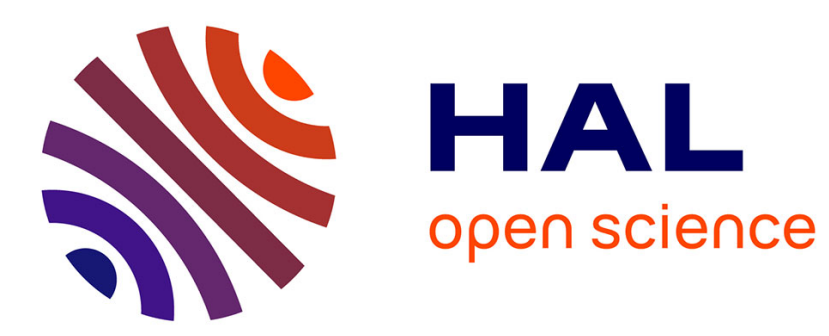

\title{
Women and Corporate Governance: Towards a New Model!
}

\author{
Viviane de Beaufort, Lucy Summers
}

\section{To cite this version:}

Viviane de Beaufort, Lucy Summers. Women and Corporate Governance: Towards a New Model!. 2013. hal-00862715

\section{HAL Id: hal-00862715 https://essec.hal.science/hal-00862715}

Preprint submitted on 17 Sep 2013

HAL is a multi-disciplinary open access archive for the deposit and dissemination of scientific research documents, whether they are published or not. The documents may come from teaching and research institutions in France or abroad, or from public or private research centers.
L'archive ouverte pluridisciplinaire HAL, est destinée au dépôt et à la diffusion de documents scientifiques de niveau recherche, publiés ou non, émanant des établissements d'enseignement et de recherche français ou étrangers, des laboratoires publics ou privés. 


\section{Women and Corporate Governance: Towards a New Model!}

\section{Research Center \\ ESSEC Working Paper 1312}

2013

Viviane de Beaufort

Lucy Summers 


\section{WOMEN AND CORPORATE GOVERNANCE: TOWARDS A NEW MODEL!}

Viviane de Beaufort $^{1}$ et Lucy Summers ${ }^{2}$

Résumé : La féminisation des conseils est un vecteur de changement et doit apporter aux organisations une valeur ajoutée, liée à la diversité de genre, donc une meilleure efficience.

Promouvoir les femmes à des postes de pouvoir, n'a cependant de sens que s'il est permis çà cellesci d'apporter, en termes de compétences et de comportements, une différence. Cela suppose de confronter le modèle masculin pour CONSTRUIRE un modèle de leadership mixte intégrant le quotient « féminin » (A.Arcier).Une étude qualitative sur les femmes et leur relation au pouvoir, menée en France et à travers le monde, publiée en octobre 2012 , a permis de formuler quelques hypothèses quant à la construction d'un modèle de pouvoir mixte intégrant des «polarités » masculines et féminines au sein de l'entreprise et des organisations (Valérie Rocoplan). C'est à partir des données de cette étude, réalisée par l'auteur avec le soutien du cabinet Boyden, enrichies des nombreuses autres publications parues sur le sujet, mais aussi de l'expérience acquise dans le cadre du programme Women Be EuropeanBoardReady, fondé à l'ESSEC, que cet article est construit. Il réalise sciemment un focus sur le genre et la gouvernance pour interpeller le bon fonctionnement des conseils. Il a essentiellement pour objet de mettre en évidence le fait que les femmes souhaitant accéder à ces mandats ou ayant accédé à ces postes partagent une vision exigeante, voire idéalisée du fonctionnement des conseils participant ainsi à la construction d'un modèle de « gouvernance pérenne » exigeant et peut être plus adapté aux défis qu'un conseil affronte désormais dans notre monde en bouleversement. Les femmes sont « moteur » potentiel de changement.

\footnotetext{
${ }^{1}$ Viviane de Beaufort Professor at ESSEC Business Schoo, Co-Director of the European Centre Law and Economics, author of several publications and conferences on Corporate Law. As the creator and Academic director of 'Women, Be European Board Ready,'she is committed to the progression of Women, Gender and diversity Issues, member of the Global Board Ready Women LinkedIn database.

Beaufort@essec.fr/Twitter : @vdbeaufort/Blog : https://sites.google.com/a/essec.edu/viviane-de-beaufort Linked-in : http://www.linkedin.com/pub/viviane-de-beaufort/8/720/aa/

${ }^{2}$ Lucy Summers is currently completing her final year of a double degree in Law and Arts (majoring in Economics and Advanced French) at the University of Queensland in Australia. Since July 2012, she has been heavily involved in the research on the legal and economic aspects of Corporate Governance and the gender dimension whilst a legal research assistance for Viviane de Beaufort.
} 
Mots clés : Gouvernance d'entreprise, dirigeance, dimension de genre, femmes et pouvoir, évolution de modèles de gouvernance, styles de leadership, pouvoir et responsabilités, femmes et conseils, administratrices, gouvernance pérenne.

Abstract: The feminization of Boards has the potential to be a vector of change, bringing "added value" to organisations through gender diversity, thus creating greater efficiency. Promoting women to positions of power only makes sense, however, if these women are allowed to bring, in terms of skills and behavior, a difference to the table. This involves confronting the masculine model, in order to BUILD a model of mixed leadership integrating the "feminine" quotient (A.Arcier). A qualitative study on women and their relation to power, undertaken in France and abroad (published in October 2012), allowed the formulation of some hypotheses in order to construct a proposition of a mixed power model that would integrate both masculine and feminine "polarities" within enterprises and organisations (ValérieRocoplan).This article is the outcome of various influences: the data of this study (by the same author with the support of the firm Boyden) which was further enriched by the analysis of other publications on the subject, as well as the experience acquired within the framework of the program Women Be European Board Ready (created by ESSEC). The article deliberately focuses on the issues surrounding gender and governance in order to address the smooth and effective running of Boards. The study essentially aims to highlight the fact that women wishing to obtain these mandates, or those who have reached these posts, share a rigorous and idealised vision of the functioning of the Boards and demand a model based on "sustainable governance" that is better adapted to the challenges which Boards face in our corporate world of upheaval. These women are potential "engines" for change.

Key words: Corporate Governance, Leadership, Board Composition, Corporate Productivity, FirmLevel Governance Outcomes, Sustainable Governance, International Corporate Governance, CrossBoarder Corporate Governance Issues, evolution of models of governance, women and boards, nonexecutive board members, gender dimension, women and power. 


\section{WOMEN AND CORPORATE GOVERNANCE: TOWARDS A NEW MODEL!}

\section{INTRODUCTION: THE CORRELATION BETWEEN GENDER DIVERSITY AND THE QUESTION OF POWER}

"The corporate world is a place of societal and social power..." (Eugene Enriquez, 'Power and desire Games in the Company', 2007); it is a place of conflicts of power, and even conflicts between people. Most of these conflicts are regulated, more or less effectively, by so-called good governance standards. Among the many issues that arise regarding governance, in the quest for greater efficiency, the 'feminisation' of Boards is a significant potential lever of change. Indeed, since more and more women have slowly been brought into positions of power within companies, inquiresinto the presence and progress of women on boards (Board of Directors, but also within Executive and ManagementCommittees) will become more commonplace, the sources of such inquires coming from:

- State intervention with the introduction of mandatory quotas (also referred to as 'feminisation'laws). Examples include Norway, Spain, France, Italy.

- Good governance practices - e.g. the German Corporate Governance Code 2010 - Section 4.1.5 or the Finnish Corporate Governance Code 2008 - Recommendation 9, the recently reformed UK Corporate Governance Code. ${ }^{1}$

- Corporate Social Responsibility Considerations: the OECD's guidelines integrate the perspective of gender diversity as a good governance practice; GlobalCompact of the UN promotes CSR, and included in its general principles is the goal of eliminating gender discrimination in the workforce.

- Pressure generated by rankings, ethical pension funds and the media.

- The efforts of European Institutions: the "incentives", and the publishing of reports which has culminated in a draft directive which sets a target of $40 \%$ women among non-executive directors of listed companies by 2020 . 
This initiation and progression of gender diversity now raises questions about the exercise of power within Boards. How do women interpret their position? Do they have the opportunity to position themselves differently, to promote different values or other management practices,in turn creating a mixed model incorporating the female quotient? (Arcier, 2002)

The existence of a specific gender dimension is controversial. As the executive search firm Heidrick\& Struggles (2011) pointed out, some people, including women, refuse to attribute certain qualities or behaviours as specific to women: "There is a question about whether women bring another perspective to the team. This prompts the question as to what extent they really bring diversity. Most of women would find it insulting to be approached for a board seat on the sole or primary basis of gender."

However, the HR literature identifies that the female gender possess a leadership style, as well as intuitive and moral qualities that are indeed different (Dugas, 2007), such as empathy, teamwork, emotional intelligence, courage, caution and/or risk aversion and common sense...

Adopting this perspective, we pose as a postulate that the collective intelligence of the whole group can be increased if women accessing positions of power maintain these supposed 'specific' qualities. (Woolley, Chabris, Pentland, Hashmi and Malone, 2010)

However, there is a risk of conformism: for a long time the work of Serge Moscovici has established that a minority group (below a proportion of one-third) adopts a conformist reflex or assimilation to the majority group (Sarfati\&Gattegno, 2007). In addition, the default stereotypes that surround exercising a leadership position makes this a complex accession to power: "The stereotype that associates men with the skills related to authority and leadership makes it difficult for women in positions of leadership and power, and women therefore tend to censor themselves or start behaving according to these ideals, meaning that they adopt male behaviours ... "(Chevalier and Khadir, 2012). 


\section{THE RISE OF THE NUMBER OF WOMEN ON BOARDS IS STILL INSUFFICIENT, FACING THESE STEREOTYPES}

\section{Some figures and facts}

A lag in the number of female university graduates and their career 30 years after graduation.

The number of female university graduates has largely increased to represent more than half of the total graduates, yet the number of women in executive committees in Europe over the next 30 years will not increase at all in the same proportion, revealing 'hi-cups' in career progression.

Graph 1: Trajectories of women on executive Committees 30 years after graduating from university

1970s, 2000s and a linear projection for 2040

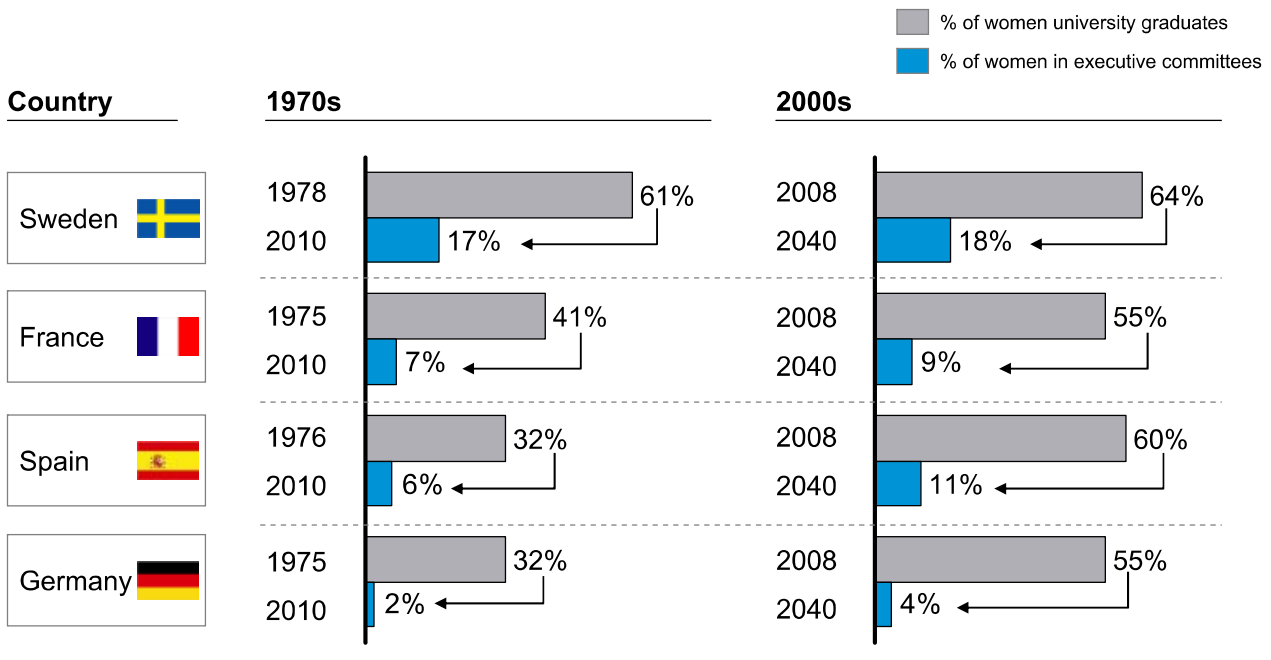

Notes: Women graduates are defined as those with the equivalent of a master's degree (Types 5 and 6 in the ISCED methodology); French equivalent: university degrees Bac + 4; executive committee statistics based on McKinsey proprietary database 2010; 2040 extrapolations based on 1975-2008 trends

Source: OECD; National statistics; McKinsey proprietary database 
In emerging markets, it is still rare to have a women sitting on a Board.

Graph 2:Proportion of companies with one or more women on the board (end-2005 vs end2011) by region

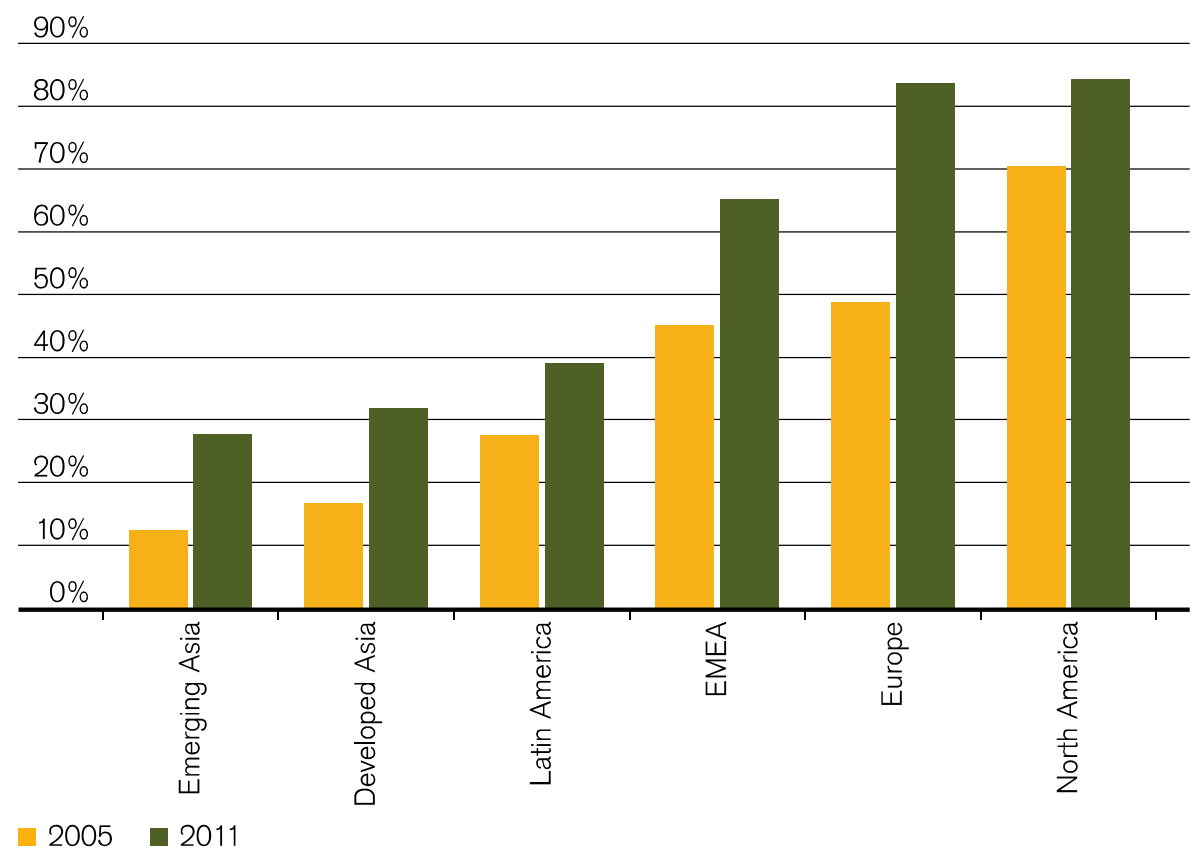

Source: Credit Suisse AG (Research Institute), 2012 


\section{The 'blocking' factors}

\section{Default Stereotypes.}

"There still exists prejudice about women in top positions - it is hard to break through the ceiling”, Isla Ramos Chavez (De Beaufort, 2012).

Valerie Rocoplan, Executive Management Coach, explains (2012): “The glass ceiling is the result of many intertwined causes. [...] Of all these causes, one of the most important and yet most complex to solve is the prejudices and stereotypes that women face”, notably:

1. Women are less available (to invest themselves in their work)

2. They lack leadership

3. Leading is a man's job

In fact, research into stereotypes identifies inaccuracies concerning the so-called negative managerial skills of women. A study by 'IMS-Entreprendrepour la Cite'(Chevalierand Khadir 2012)from interviews of 908 male and female managers were able to confirm the existence of gender stereotypes: $44 \%$ of the male managers and $51 \%$ of the female managers surveyed, concluded that men and women have different professional skills. Men represent authority and leadership, women: listening and empathy. These stereotypes therefore serve as a hindrance for women aspiring to positions of power. Thus, women have a more complicated, less obvious relationship with power.

Research has consistently shown that as a woman becomes more 'powerful', she becomes less liked, while, on the other hand, as a man climbs the corporate ladder, he becomes more liked! Why is there a negative correlation between power and likability for women?

Sheryl Sandberg ${ }^{2}$ argues that this is a consequence of negative gender stereotypes propagated byour society since childhood, but that this can be changed: 'the more we have women who are leaders, the more we will start to associate leadership characterises with women, and the less we will be inclined to call our little girls bossy. With every woman who channels her inner self-confidence, and then 
puts her hand up to be part of a decision-making body, we do our part to change these negative stereotypes.’

A recent survey of 7280 leaders by Zenger Folkman(2012) revealed that, at all levels, women scored better on 12 of the 16 skills that constitute exceptional leadership. Women also 'outscored' men in qualities that have long been considered male strengths, notably being able to - take Initiative and Drive for results. It was noted that men 'outscored' women significantly on one single management skill - the ability to develop a strategic perspective. According to Jack Zenger and Joseph Folkman (2012) this is simply due to the fact that "Top leaders always score significantly higher in this competency; since more top leaders are men, men still score higher here in the aggregate. But when we measure only men and women in top management on strategic perspective, their relative scores are the same."

\begin{tabular}{|lll|}
\hline Table 1: Skills and competences required by Leaders & & \\
\hline Competence & $\begin{array}{l}\text { Male mean } \\
\text { (\%) }\end{array}$ & $\begin{array}{l}\text { Female mean } \\
\text { (\%) }\end{array}$ \\
\hline Takes Initiative & 48 & 56 \\
Practices Self-Development & 48 & 55 \\
Displays High Integrity and Honesty & 48 & 55 \\
\hline Drives for Results & 48 & 54 \\
Develops Others & 48 & 54 \\
Inspires and Motivates Others & 49 & 54 \\
Builds Relationships & 49 & 54 \\
Collaboration and Teamwork & 49 & 53 \\
Establishes Stretch Goals & 49 & 53 \\
Champions Change & 49 & 53 \\
Solves Problems and Analyses Issues & 50 & 52 \\
Communications powerfully and prolifically & 50 & 52 \\
Connects the Group to the Outside World & 50 & 51 \\
Innovates & 50 & 51 \\
Technical or Professional Expertise & 50 & 51 \\
Develops Strategic Perspective & 51 & 49 \\
\hline Source : Zenger Folkman Inc., 2011 & & \\
\hline
\end{tabular}


Why women are so poorly represented in places of power and leadership?

The consulting firm 'The Boston

Consulting Group'published a report

in 2012 identifying several factors

that they consider barriers to the

rising the numbers of women in

decision-making forums (see Exhibit

2). The most cited obstacles of

corporate culture and lack of

diversity management that are

driving the under-representation of

women are:

- Inadequate management of leadership pipelines

- Lack of gender diversity awareness among management

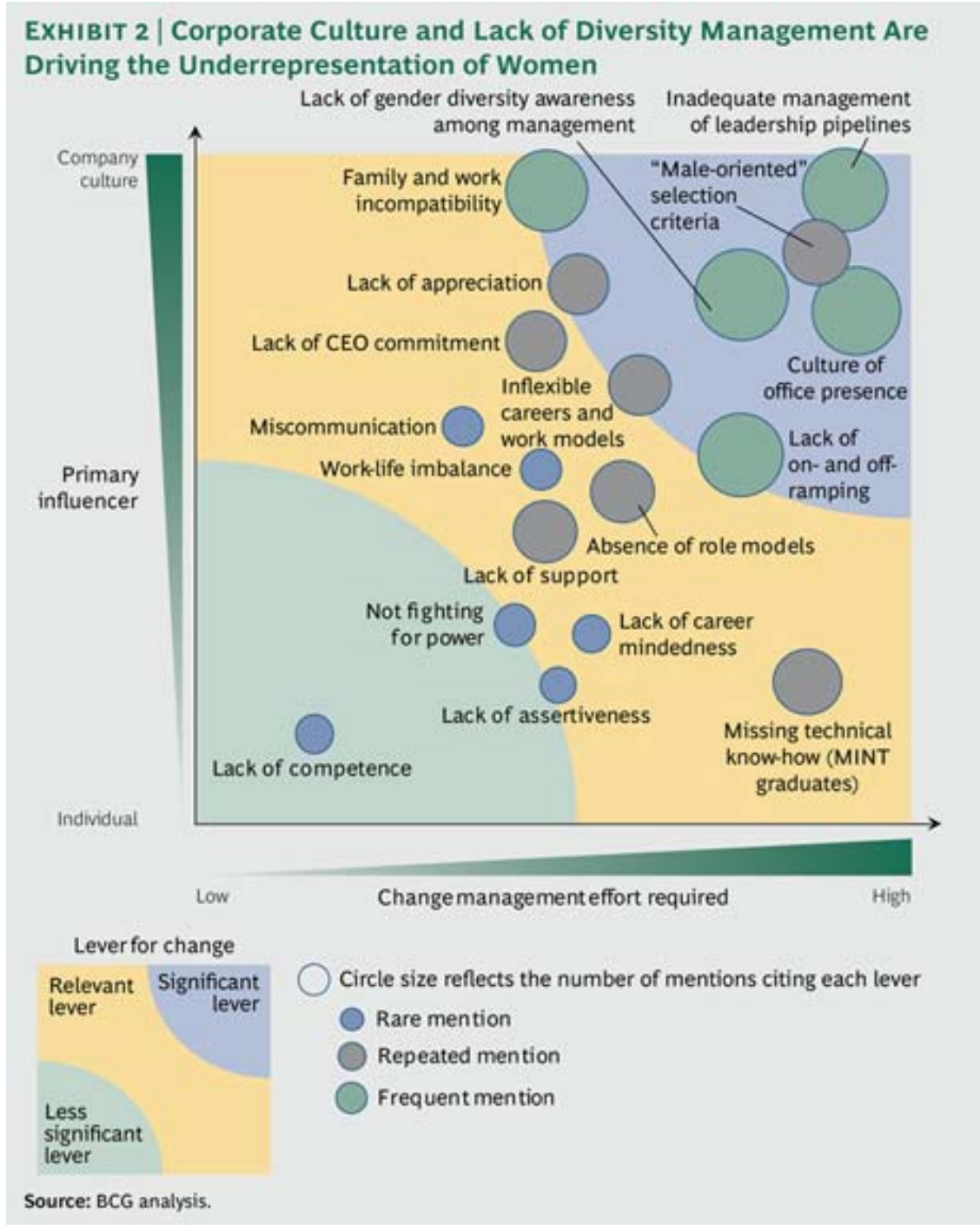

- Culture of office presence

- Lack of on- and off- ramping

- Family and work incompatibility

- "Male-orientated"selection criteria

The recent study in 2012 byEgonSehnder International on gender diversity solutionsfocused on the need to identify other women candidates who remain "under the radar". There are several levers for change: the age of identification of high potential remains open, accepting a less linear and phasebased career evolution, and the evolution of the types of skills that are sought by Boards - women being often in support functions (Human Resources, communication, law). 


\section{The 'Internal’ Barriers.}

The results from the study "Women and Power" (De Beaufort, 2012) ${ }^{3}$ remind us that it important to acknowledgethat there are internal barriers to women climbing the corporate ladder, and these are within a woman's control!In a brainstorming session for the study, the Alumni of the "Women, Be European Board Ready" Executive programme ${ }^{4}$ conceded that in addition to highlighting the skills that women can 'bring to the table', “we must also recognise certain female 'weaknesses': absence of self-confidence, the 'imposter complex', the absence of a 'career plan'... and, above all, the difficulty that we experience when needing to delegate". These 'weaknesses' are internally driven barriers that need to be discussed so that they can be rectified.The U.S. study in 2011 on the same topic,by Dr Anne Perschel and Jane Perdue, concurred that the typical internally driven barriers that face women include lack of self-confidence, andhesitancy to speak up or act assertively.

"Self confidence is lacking in the female workforce and we are working on it"(Chevalier and Khadir, 2012). Research shows that women have a tendency to question their skillset and underestimatetheir ability to take on new leadership roles: "Another obstacle is that women often say no to new challenges" (Chevalier and Khadir, 2012)or as Warren Buffett puts it, "too many women continue to impose limitations on themselves, talking themselves out of achieving their potential” (2013).

What about the internal inner-critic that causes women to shun the thought of saying something that may not gain support from the majority group (men)? As Sheryl Sandberg preaches, women must learn to 'lean in' so that minority voices shed new light on business decision-making possibilities. As a Director of a DG at the European Commission interviewed in the study "Women and Power"(De Beaufort, 2012) summarised: "I regard courage as one of my most important personality traits. If you are really courageous... eventually one will succeed.” 


\section{The Tools}

\section{The leverage effect of Quotas.}

The 'feminisation' of Boards remains a CHALLENGE and requires an accelerated effect.

Accordingly, currently seventeencountries have, in recent years, established quotas, including

Denmark (2000), Norway (2003), Ireland (2004), Finland (2004), Iceland (2006), Spain (2007),

France (2011), Belgium (2011), Italy (2012).

The figures speak for themselves: the introduction of a female quota creates a significant legal lever. Analysis of quota policies that have already been implemented tends to show the effectiveness of this legally constructed tool.

Industrialised Europe and Nordic Countries leading the global change due to the implementation of Quotas

Table 2A:

Regional Breakdown of percentage point changes since December 2009 and March 2013

\begin{tabular}{|l|c|c|c|c|}
\hline Region & $\begin{array}{c}\text { \% point change in } \\
\text { women on boards }\end{array}$ & $\begin{array}{c}\text { \% point change in } \\
\text { companies with at least } \\
\mathbf{1} \text { woman }\end{array}$ & $\begin{array}{c}\text { \% point change in } \\
\text { companies with at least } \\
\mathbf{3} \text { women }\end{array}$ & $\begin{array}{c}\text { \% point change in } \\
\text { companies with Female } \\
\text { Chairs }\end{array}$ \\
\hline Australia/New Zealand & $5.4 \%$ & $23.9 \%$ & $5.7 \%$ & $0.3 \%$ \\
\hline Industrialized Asia & $0.5 \%$ & $4.1 \%$ & $1.3 \%$ & $0.3 \%$ \\
\hline Industrialized Europe & $4.0 \%$ & $17.4 \%$ & $11.0 \%$ & $0.5 \%$ \\
\hline Nordic Countries & $3.3 \%$ & $4.8 \%$ & $11.2 \%$ & $4.0 \%$ \\
\hline US/Canada & $1.8 \%$ & $6.7 \%$ & $4.9 \%$ & $0.4 \%$ \\
\hline Americas & $0.1 \%$ & $3.3 \%$ & $-2.1 \%$ & $-3.2 \%$ \\
\hline Emerging Asia & $0.3 \%$ & $1.8 \%$ & $0.9 \%$ & $-0.1 \%$ \\
\hline Emerging Europe & $1.5 \%$ & $3.2 \%$ & $3.7 \%$ & $-0.3 \%$ \\
\hline Middle East and Africa & $2.6 \%$ & $6.2 \%$ & $6.0 \%$ & $-1.9 \%$ \\
\hline Global Change (3yrs) & $1.66 \%$ & $6.4 \%$ & $4.8 \%$ & $0.3 \%$ \\
\hline Global Ex-IndEur/ & $\mathbf{0 . 8 \%}$ & $\mathbf{3 . 5 \%}$ & $\mathbf{2 . 8 \%}$ & $\mathbf{0 . 1 \%}$ \\
\hline Nordic Change (3yrs) & & & & \\
\hline
\end{tabular}

Source: GMI Ratings, 2013 
Table 2B:

Current levels of women on boards by Region as at March 2013

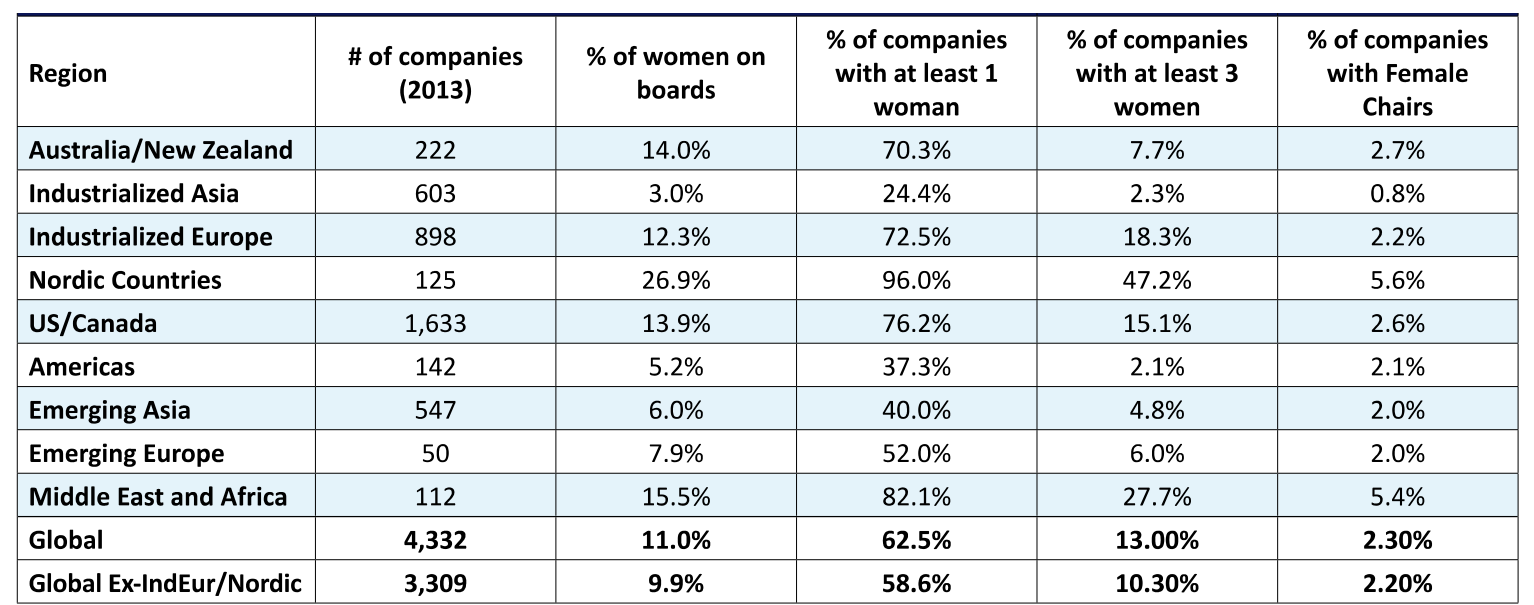

Source: GMI Ratings, 2013

\section{The Norway example}

In 2004, Norway introduced a legal quota of $40 \%$ of women on Boards of Directors, with the following results:

Graph 3: Percentage of Women on the Board of Directors (Norway)

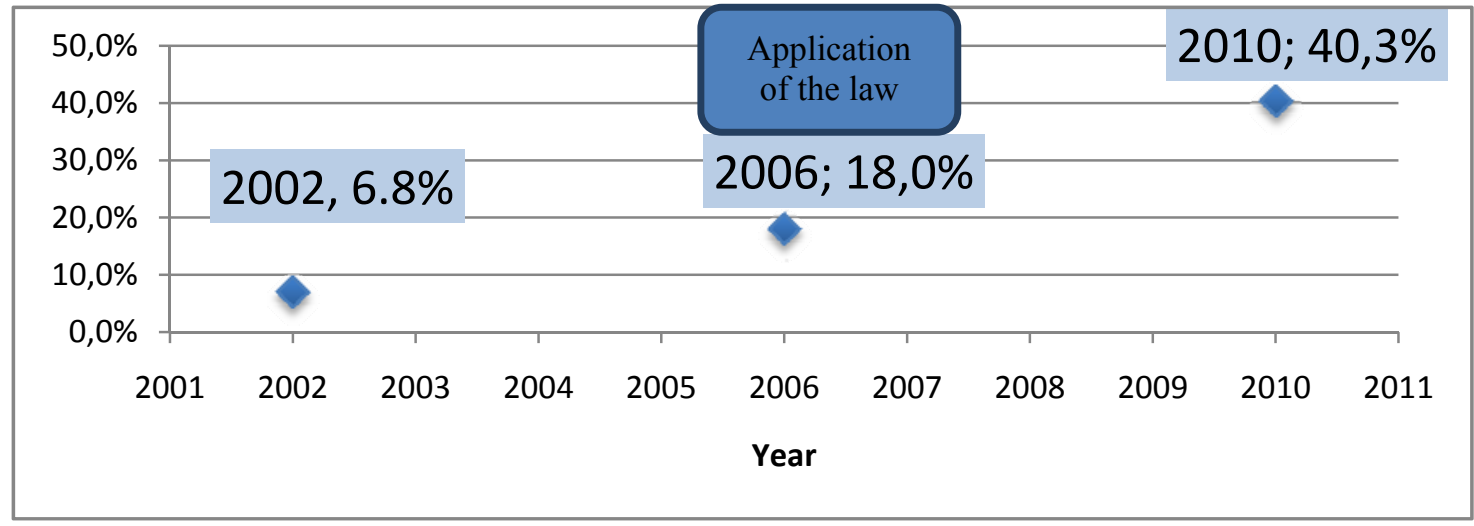

Source: Natividad, 2010 
In 2011, the French parliamentfollowed Norway's lead with the introduction of the Copé-

Zimmermann law, which sets a quota with a target of $20 \%$ of women on Boards of Directors by 2014 , and $40 \%$ by the end of 2017 .

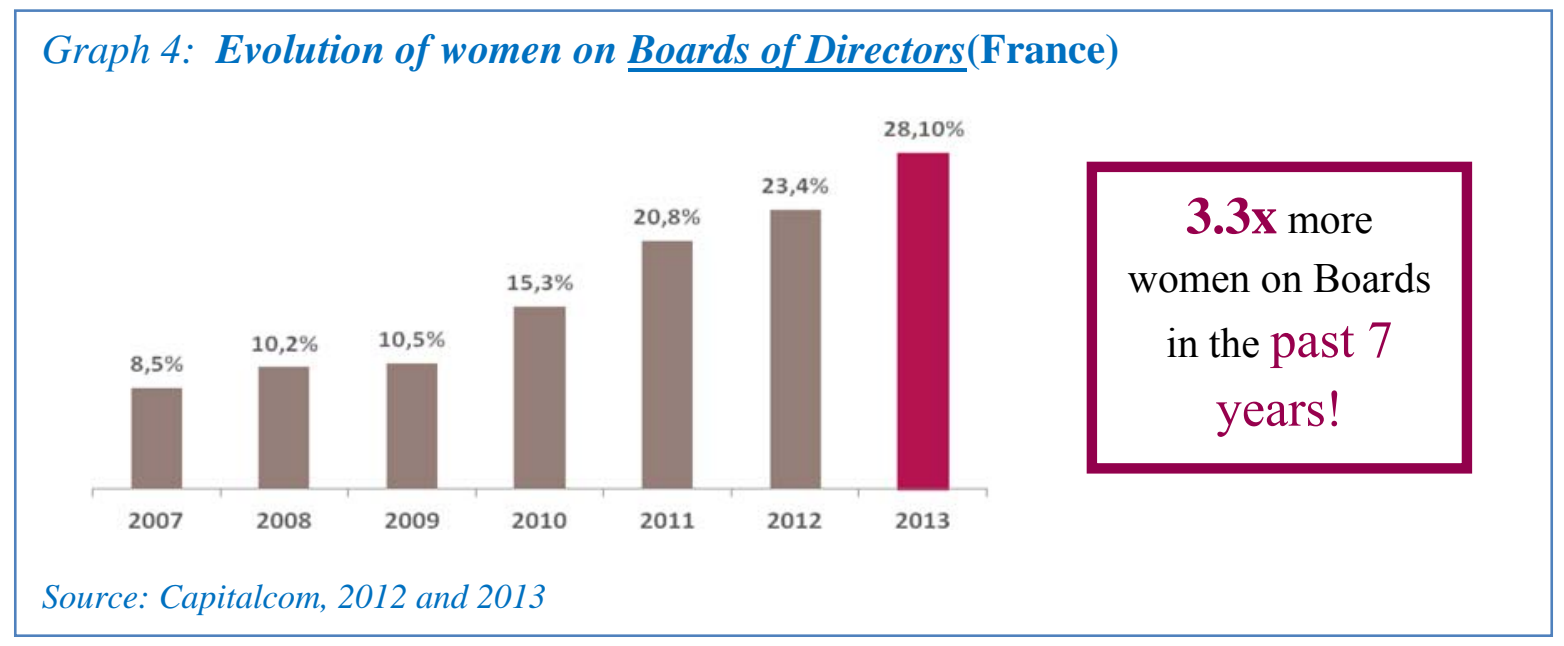

Compared with the situation on Management and Executive Committees:

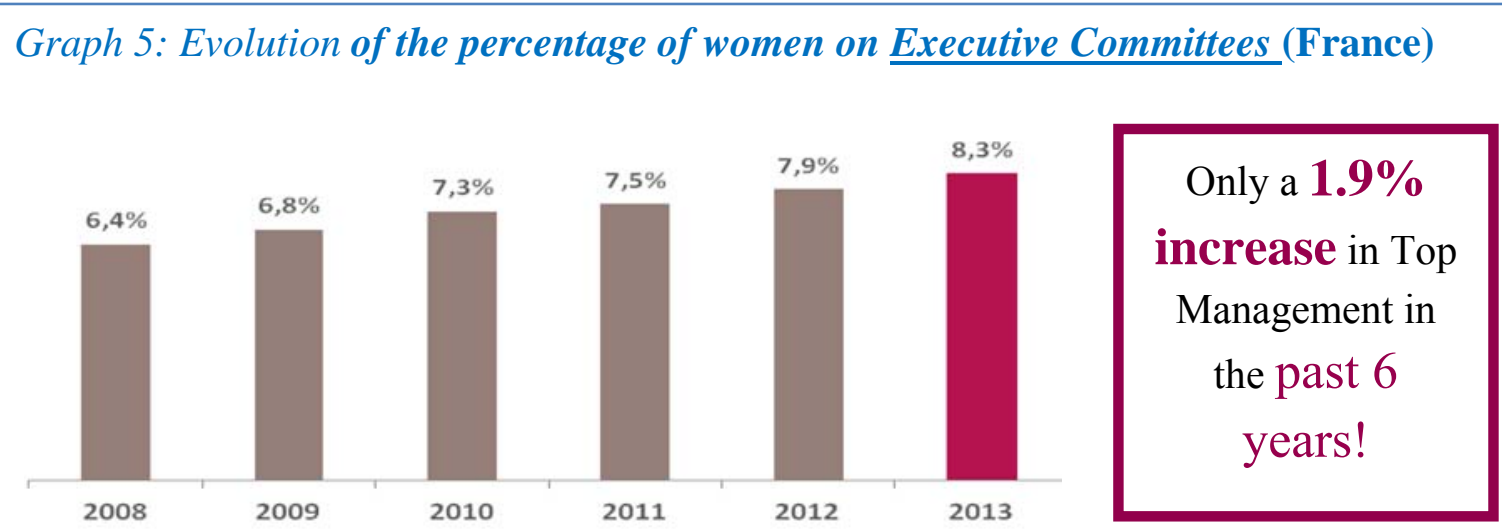

Source: Capitalcom, 2012 and 2013

In France, the law sets quotas for companies that 'employ an average of at least 500 permanent employees and have a turnover or total assets of at least 50 million euros,' which applies to some 2,000 companies. The law provides that:

- If, at the date of publication of the law, one of the two sexes is not represented on the Board of Directors, the appointment of the next Director must be of this sex.

- On 1 January 2014, the proportion of members of the Board of Directors of each sex cannot be less than $20 \%$

- On 1 January 2017, the proportion of members of the Board of Directors of each sex cannot be less than $40 \%$ 
As well as two sanctions:

- The invalidity of any appointment in violation of the law (but not the nullity of the proceedings to which the administrator has already participated).

- The suspension of remuneration of the Directors until the board meets the quota.

\section{The recent efforts of the United Kingdom encouraging the market to regulate the problem}

The UK has long been opposed to the enforcement of mandatory quotas in order to achieve an improvement to the representation of women on Boards. However, in response to an effective plateau in the new appointments of women directors between 2008 and 2010, the UK Government, in 2011, published an independent enquiry into women on Boards, the 'Lord Davies Report'. The report revealed that "in 2010 women made up only 12.5\% of the members of the corporate boards of FTSE 100 companies. This was up from 9.4\% in 2004. But the rate of increase is too slow”, concluding that "at the current rate of change, it will take over 70 years to achieve gender-balanced boardrooms in the UK”.

The 2011 report proposed 10 recommendations for government and business in achieving urgent change in the proportion of women representing corporate boards, with the key notable recommendation being that the FTSE 100 Boards should aim for a minimum $25 \%$ female representation on their boards by 2015. The following year, the 'Cranfield School of Management's Female FTSE report 2012' disclosed the progress made since previous year's recommendations: "Overall the percentage of board directors who are female is $15 \%$, an uplift of $2.5 \%$ on what was a three year plateau"(Sealy\&Vinnicombe, 2012). Lord Davies (2012) published the first annual progress report in parallel with the Cranfield Report, where he celebrated the start of " $a$ culture change taking place right at the very heart of British business in relation to how women are seen within the workforce. [...] However, I must also emphasise that efforts need to be ramped up and the speed of change accelerated if we're to avoid Government interference. [...] We were always clear that $25 \%$ is the minimum starting point, not the ultimate goal." 
Lord Davies'most recent progress report in 2013 expressed concern that after a short period of growth in 2011 and 2012, the last six months have actually seen a decrease from $17.7 \%$ to $17.3 \%$, signalling that the momentum appears to be slowing, as well as the fact there has been much less progress in executive appointments at the top.

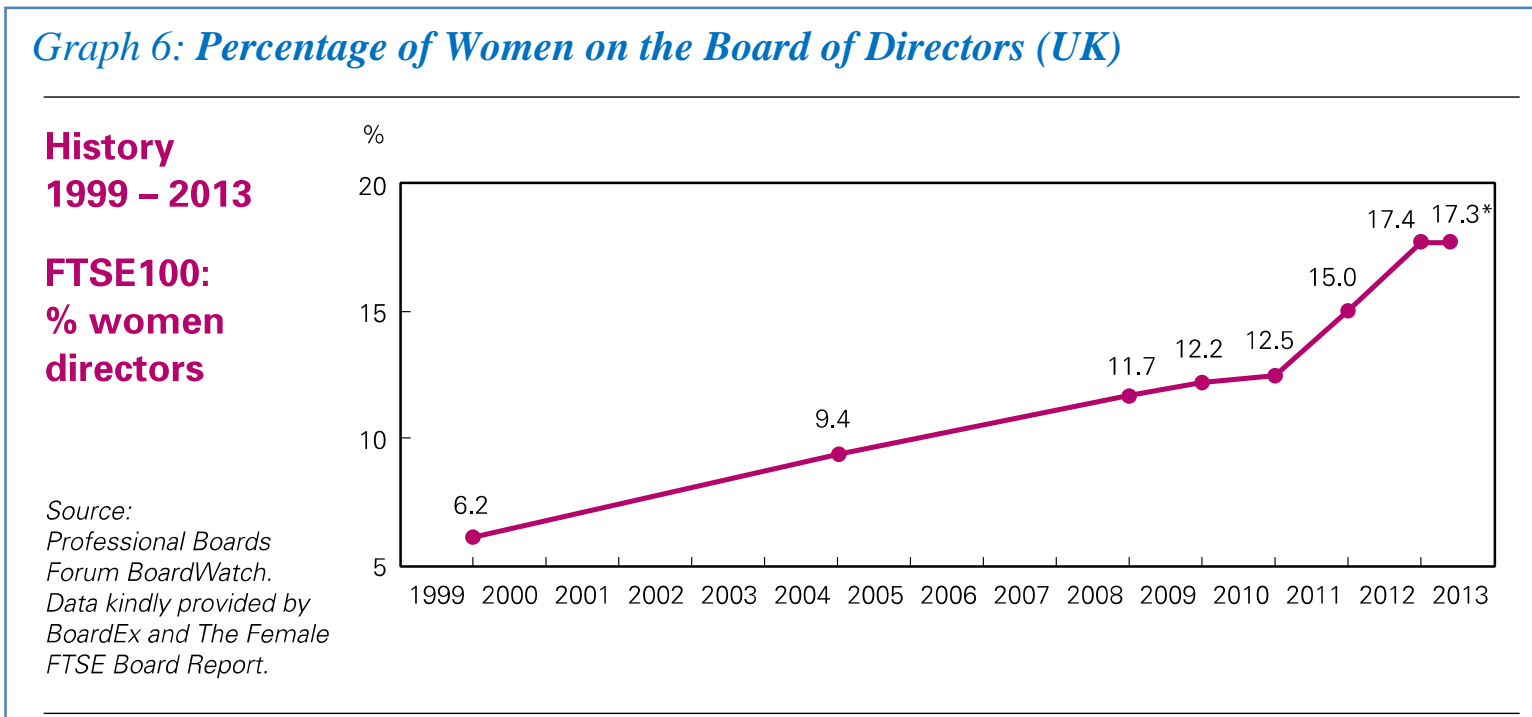

Source: Women on Boards (Progress Report), April 2013.

Business Secretary Vince Cable summarised the consequences of such complacency settling in:

“Government continues to believe that a voluntary led approach is the best way forward. But today's report also serves as a timely reminder to business that quotas are still a real possibility if we do not meet the 25\% target of women on boards of FTSE 100 companies by 2015.”

The 2013 parallel publication ofthe "Cranfield School of Management's Female FTSE report 2013" reiterated this warning: "At Cranfield we have stood steadfast against quotas on the basis that Chairmen must understand the benefits of gender diversity and commit to achieving it. Undoubtedly a number of Chairmen do get it and see a gender balanced board as the 'newnormal'. Unfortunately too many Chairmen choose to ignore the issue in the false hope that it will go away. Viviane Reding's demanding legislation is on its way and it goes far beyond Lord Davies' recommendations. It is becoming a matter of urgency for those companies that do not have a gender balanced board to let go of their board stereotypes and appoint more creatively"(Sealy \&Vinnicombe, 2012). 
Arguments against the implementation of Quotas.

'The risk of replacing a competent person with one who is less competent' is an argument that is often heard! However, in using the same methods and criteria as used for the recruitment of male Board members, this argument of a risk of lowering the competence level, and in turn a decrease in the value of the Board, seems specious and unfounded.

Quotas are also seen as likely to cause problems for those that benefit: these people become stigmatised, considered as only being in their position due to the fact that they have certain characteristic that gave them a privilege, in this instance: the female gender.

Finally, quotas are sometimes presented as unattainable in view of the small number of people with the required characteristics and skills (Stone, Cornet \&Cusumano, 2012).

Although the debate remains contentious in Europe, since the European Commission's proposal, more and more people, including Directorseventually consider the quotas as a "necessary evil".

\section{QUESTION : ARE QUOTAS OF UTMOST IMPORTANCE? \\ ((is a legal 'boost' necessary, or do good business practices suffice)}
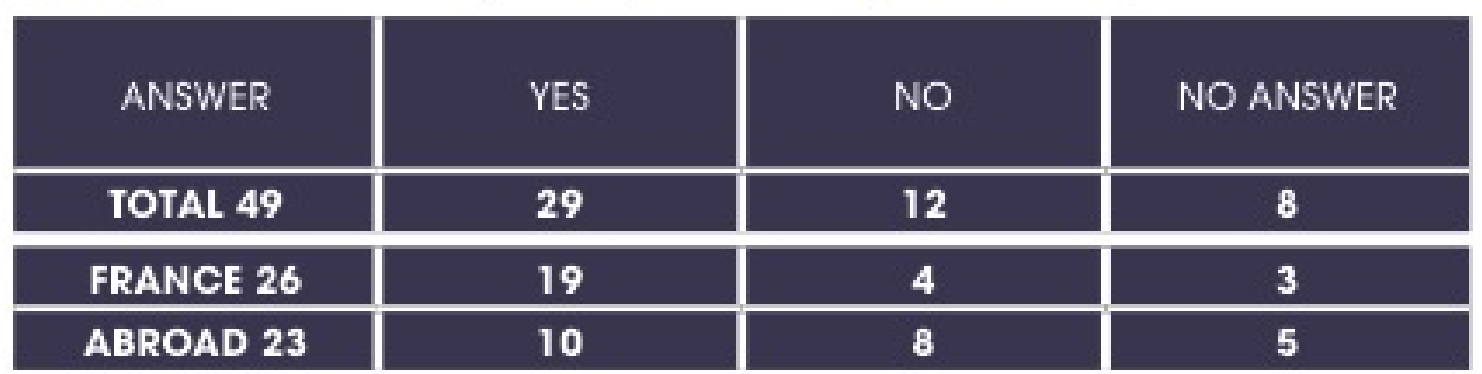

FRANCE 26 ABROAD 23

\begin{tabular}{|l|l|}
\hline 19 \\
\hline 10
\end{tabular}

\begin{tabular}{|l}
4 \\
\hline 8
\end{tabular}

5

Source: Study “Women and Power”, Viviane de Beaufort, October 2012. 
Other tools to promote Gender Diversity.

Among the various tools referenced by aBCG Study (2011):

Graph 7: Percentage of companies that have put in place measure to promote Gender Diversity

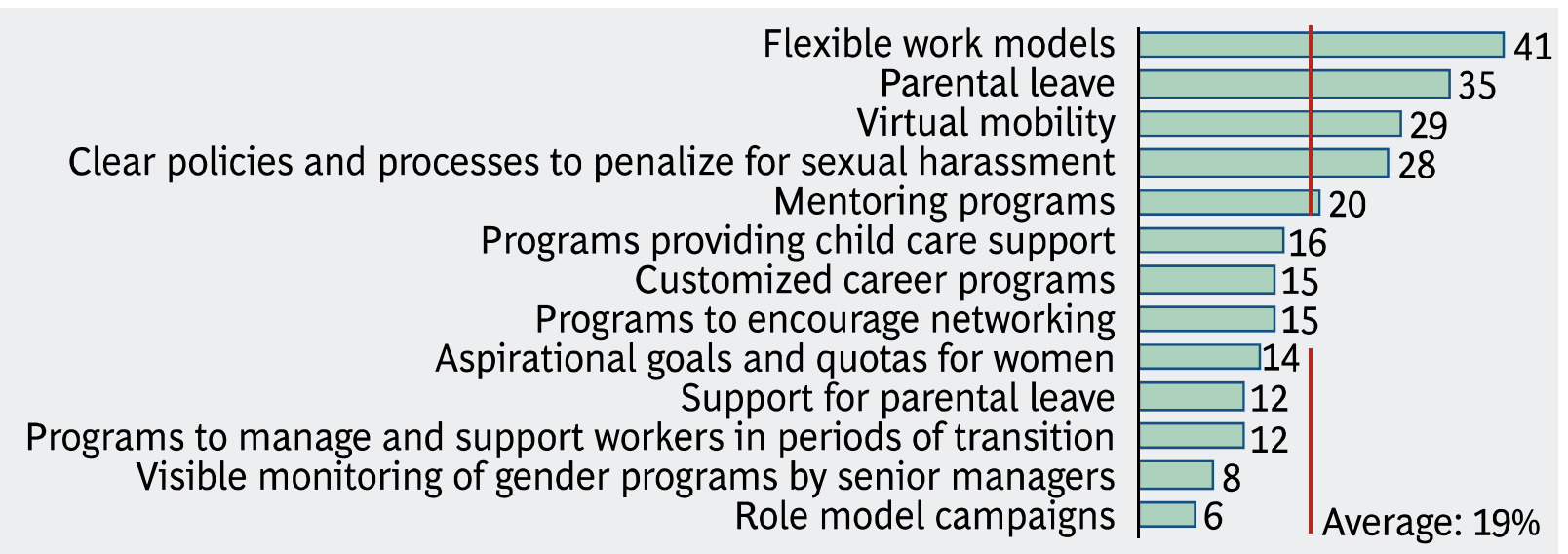

Source: BCG Perspectives, Hard-Wiring Diversity into Your Business, 2011

It appears that the member states of the European Union have adopted a range of different measures:

Table 3: The Adoption of Gender Diversity measures, by European country

\begin{tabular}{|c|c|c|c|c|c|c|c|c|}
\hline Measures to promote gender diversity & $\begin{array}{c}\text { Europe } \\
\text { Percentage of } \\
\text { companies } \\
\text { implementing } \\
\text { each measure }\end{array}$ & Finland & France & Germany & Italy & Netherlands & Russia & Spain \\
\hline Flexible work models & $41 \%$ & 1 & 1 & 2 & 1 & 1 & 3 & 1 \\
\hline Parental leave & $35 \%$ & 2 & 4 & 1 & 3 & 2 & 1 & 2 \\
\hline Virtual mobility & $29 \%$ & 3 & 1 & 4 & 4 & 4 & 2 & 4 \\
\hline $\begin{array}{l}\text { Clear policies and processes } \\
\text { to penalize for sexual harassment }\end{array}$ & $28 \%$ & 4 & 3 & & & 3 & & 3 \\
\hline Mentoring programs & $20 \%$ & 5 & & 5 & & & 4 & \\
\hline
\end{tabular}

Source: BCG Perspectives, Hard-Wiring Diversity into Your Business, 2011 
Transparency as a tool for development.

Listed companies are now required to include a statement on Corporate Governance in their annual report. Adding a section on DIVERSITY would contribute to the transparency of the subject and would create a means of comparison (a benchmark). The information that should be includedconsists of:

- Detailed and diverse statistics

- The progress of short-and medium-term objectives

- Tools to be implemented, such scorecards (Landel, 2009)

\section{Supporting Women.}

Women may face problems of legitimacy in the dominant male model. Mentoring and targeted training with coaching on traits, as proposed by the first programme in France dedicated to women on this topic (inspired by the Canadian model),"Women, Be European Board Ready"will assist women in acquiring the "skills \& traits" necessary. ${ }^{5}$ 
A WOMEN'S SEARCH FOR A POWER 'TO ACT', RATHER THAN A POWER 'FOR ITS OWN SAKE'

Research in management identifies the male norms tend to lead to a quest for power for power's sake - the power 'to be' as opposed to "feminine" power model'to do' or 'to act': power exercised in the public interest, generally in a more collective way, with a strong sense of personal responsibility visà-vis others. In «Et si les Femmes réinventaient le travail”(And if women reinvent the working world), Cristina Lunghi (2001)affirms that one must not believe that women do not appreciate power, but that they see it as a means to get things done, rather than for its external show, or just to possess it.

"It seems to me that women who have power are anxious to do something with it ... When we accept a role, it is first to do something more than to be something”, Arlette Chabot (interviewed in Sarfati\&Gattegno, 2007).

"I never sought out power in order to be powerful. I believe in a different form of power: to do something for yourself and for others", Laurence Parisot, (interviewed in Sarfati\&Gattegno, 2007).

“[Women are] less tactless, more preoccupied by the power to achieve results”, S.Paix(De Beaufort, 2012).

"POWER:this notion is very different for men and women. The attributes of power for men are status, the signing power, and formal prerogatives. Women give precedence to freedom of action, decision power, and the ability to get things done”, S. Ouziel(De Beaufort, 2012). 


\section{A career motivated by the desire to do good}

In the study (De Beaufort, 2012), the great majority of women interviewed actually state that they do not build their career in connection with an aspiration to power. Rather than an elaborate strategy, women find themselves in a position of power based on chance, opportunities, and choices always in connection with the interest of the mission and the job.

"No career plans, because it is animpediment to freedom", D. Ernotte-Cunci.

"I have let things come all along my path. I let my instinct and my desires guide me, I have always endeavoured to have fun in my successive positions", S.Paix.

“The enterprise... should in a country such as ours regain its [letters of] nobility. I wanted to participate in the work of (re)construction," S. Lochmann.

"I plan to influence the role of the company in its social and economic environment",N.Balla. "Is there something close to my heart? Evolving business models, contributing to thinking differently”, D.Elyaacoubi.

"To shake things up, to advance a dynamic and innovative conceptions of the general interest”, A.Bricard.

In other words, it appears that women will seek positions of power and/or mandates on Boards with a strong desire to "make things happen".

"The conquest is fundamentally a masculine drive. Men have developed a system of values consistent with their own behaviour, a model that is based upon the conquest: before exercising power, we must be able to conquer it. Our system still glorifies the desire for conquest, which has forced women to fight men on the register of the conquest, which is against nature”,RafikSmati (Bramly, Carminati-Rabasse et al, 2012) 
QUESTION : DO WOMEN DELIBERATELY PLAN THEIR RISE TO THE RANKS OF POWERFUL POSITIONS?

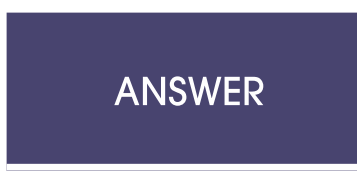

TOTAL 49

FRANCE 26

ABROAD 23

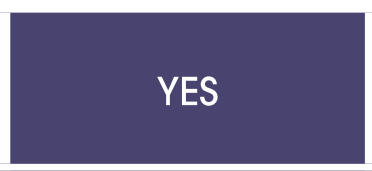

9

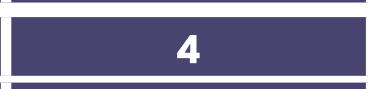

5

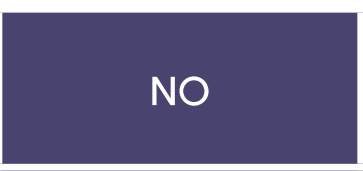

29

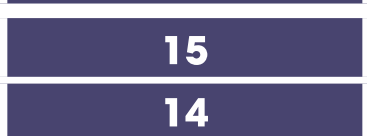

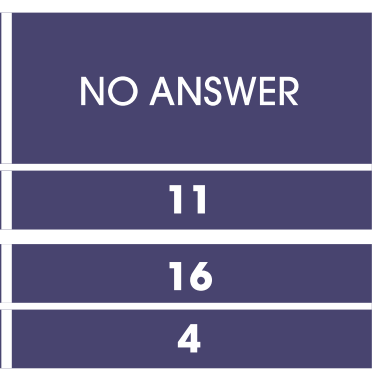

Source: Study “Women and Power”, Viviane de Beaufort, October 2012.

\section{The search of a power exercised collectively}

The warlike conquest and solitary exercise of vertical power does not appear to be a suitable model for women, who desire a more collective decision-making forum.

"Power isolates, which is what I hate about it ... I only function well when surrounded by others”, S.Paix(De Beaufort, 2012).

"When we are at the top, we are alone”, D.Reiniche (Gilbert, 2012).

"It is important to take into account all dimensions of power, including the more dramatic aspects: understand that all your actions and words are signals. Power makes you lose some of your freedom and demands high standards", Francine Weber (interviewed in Rocoplan\&Vanbremeersch, 2011).

"Of course power isolates, but less for women than for men as they are less carried away by power games”, I.de Kerviler (De Beaufort, 2012).

"Power isolates, because the perceptions of others change. Learning to surround yourself with others is critical. I think women do this more spontaneously, and are therefore less likely to feel isolated”, V. Rocoplan (De Beaufort, 2012).

"Nothing is more foreign to me that the "phenomenon of court". Instead, I take note of a lot of opinions from various sources, I try to "harness" my goal of always uniting opinions", A. Bricard(De Beaufort, 2012). 


\section{The fear, hatred of, or simply a disinterest in power games}

The majority of interviewees (De Beaufort, 2012) mentioned some discomfort in the face of conflict, feeling that it is unnecessary and that there are other ways of going about resolving problems. In this way, women naturally seek mediation rather than confrontation, but they do not hesitate to assert their position (or opposition) if they feel that there is a breach of their values. They are therefore particularly courageous and committed to their causes.

"When it comes to a power struggle, I try to understand the positions of others, I state mine, I try to take on the concerns of the opposing positions in the interest of the company ... I do enter into opposition” N. Balla.

"I feel that it is my right and duty to always give my opinion", Anonymous.

"I have already objected to a decision and I've noted that courage is more prevalent in women on this point: to have the ability to challenge and confront the point of view of the majority of the company”, B. Dalibard.

"Women are not afraid, they say things clearly. If a woman does not want to enter into open conflict, her resistance may be leaving the Board”, Anonymous.

"I do not try to avoid battles... I have been known to strongly express disagreement when decisions went against my values. In such cases... I try... to use argument, to convince, and to find allies,"A.Bricard.

“Women are ready to defend their position if a disagreement arises. ”S.Ouziel.

"Power only isolates according to the way you exercise it. If you are too far removed from the employees, then it isolates and you're out of the game. The exercise of power is on the contrary a great source of collective energy.”, N. Mesny. 


\section{A systematic reliance on skills (for reassurance) and the duty towards a special responsibility for women}

\section{The importance of expertise.}

All of the interviewees of the "Women and Power"study (De Beaufort, 2012) cited skills as a priority for success; the eternal female "imposers" justify their position and their career progression by hard work and competence:

“A woman's professional background and expertise is very important in gaining a legitimacy that does not only depend on quotas. Women are very much judged on achievements and "accomplishments", where as men have the privilege to sometime be judged on their potential. Women do not have the right to make mistakes, so we need to arrive well prepared for Boards”, B.Dalibard.

"I've always be selected based on my competences",Anonymous'

"Skills and degrees help a woman in her quest for success”, D. Elyaacoubi.

"Women are often more advanced in the knowledge of their accounts ... they need to be completely factual if they are to convince others”, D. Ernotte-Cunci.

"It is important that they have the professional experience and that they are legitimate", A-S Fauvet.

“Academic 'training' is not enough: women must be legitimate in their function and sector across different regions. The professional background is therefore important, though women are often disadvantages compared to men in terms of the quantity and depth of professional experience expected", C. Lewiner.

“A woman must have a strong professional legitimacy (a professional career), to enter a Board. Otherwise, she will be discredited!”,P. Sourisse. 
"The hardest part for mewas being a quota. When one is a female quota, it means that we are illegitimate, and so must prove ourselves twice as much asothers that you are a legitimate Board member”, S. Auconie.

\section{The sisterhood?}

Notwithstanding the famous Queen Bee complex, which probably still persists in some sectors where women are scarce: "A woman that is already on a Board can have an ambiguous position with respect to the arrival of other women: on the one hand it can be said she will be "less alone", even if at the same time it reduces her difference and originality,"M. Dubouloy. "It would seem that...among the women having acceded to positions of power, almost all women now feel a collective responsibility: when they can, they act on behalf of women" Anne Cécile Sarfati and HervéGattegno (2007).

"The female pioneers, according to their own admissions, have for a long time worked alone. Being the first allowed them to get all the attention and limelight. According to witness accounts, many have fully savoured this period of grace until they got bored with meetings attended mainly by male homologues. They have then turned their attention to the younger generation, to help them progress in their careers", E.Gagliardi.

"We need all the women who have power or influence ... to assume this special responsibility: women who run very large corporations, what are they doing towards ensuring that there is parity on their Boards?”,Elizabeth Guigou(interviewed in Sarfati \& Gattegno, 2007).

"I see myself more as an influential woman, a woman providing openings, than as a woman in power. In any case, as someone who tries to move the demarcation lines, to jostle rigidities, to overcome preconceived ideas”, VéroniqueMorali(interviewed in Sarfati \& Gattegno, 2007).

"Is there any solidarity among women? I try to build it but it is not systematic and I do not want to give a sense of ostracism based on gender!»,S.Lochmann(De Beaufort, 2012). 
"Is there solitude? Yes, absolutely. I am the 2nd woman on the Executive Committee with Christine Albanel and we have developed the habit of sitting side by side. When I am at the office, on the ground, a natural solidarityoccurs with the female Heads”,D.Ernotte-Cunci (De Beaufort, 2012).

"In all of my actions I favour the respect of parity between women and men”, A. Bricard(De Beaufort, 2012).

\section{WHAT POTENTIAL CHANGES TO CORPORATE GOVERNANCE ARE ESSENTIAL?}

\section{Sustainable Governance for Boards}

\section{Exerciseof power or sense of responsibility.}

It is striking that all the women interviewed in the study (De Beaufort, 2012) shared an acute sense of responsibility. It is a trait that is characteristically and recurrently mentioned by the interviewees, regardless of their geographical origin: "an understanding of the business, alertness and vigilance, in order to try to identify potential risks and make strategic choices to verify that the future of the group is more or less assured, to ensure the coherence of everything”(Gilbert, 2012).

Power "to do" creates a special responsibility:a pattern that emerged in the interviews conducted by the study "Women and Power" (De Beaufort, 2012) as a commitment toleading change for the public interest.

"Women testify to having jeopardised their own career to do what they felt was their duty, preferring the correctness of the action over manipulation, which has ensured them a future! In this way, powerful women feel totally responsible for their actions, for better or for worse”, E. Gagliardi.

“Courage and power are linked. To exercise power, it takes a lot of managerial courage. Decisions are sometimes difficult to make”, N. Balla. 
"I listen to the arguments of my team, and I take particular notice of external advice that I seek, but when it comes to making a decision, I take responsibility without hesitation, fear, or remorse", A. Bricard.

"I very much like the status of English Director. Before joining a Board, according the English law, one must sign a paper that says you engage your personal responsibility in your role as Non-Executive Director”, Anonymous.

"Courage is the key function of a manager. What matters first and foremost is courage; it's a value that earns one respect. It is courage that makes you want to follow someone or not", S. Paix.

"Women are more aware of their responsibility even if courage is not always rewarded", I. de Kerviller.

"My role and mission are driven by a strong conviction that nothing is more exciting (but also more difficult) than to flush sterile habits and replace them with new behaviours that create value and/or greater goodness” A. Bricard.

\section{Respect for rules and ethics.}

It is evident that women have a meaningful commitment to standards. In all the interviews of the "Women and Power" study (De Beaufort, 2012), rules are valued, the respect for rules above all. The rules and the ethical framework are clearly identified as a means of protection against the arbitrary abuse of power of all kinds. The principles of good governance (public or private) are a bulwark against ethical deviance. Even the quota laws, sometimes difficult to accept because women wanted 'to get there without them', have been clearly identified as a creator of legitimacy.

Women are often attached to processes, mainly due to the protection against arbitrariness and personal appropriation of power, yet it is mainly the expectation of ethics and morality that is embraced by the women interviewed. Generally speaking, the women interviewed (De Beaufort, 
2012) regardedcompliance, regardless of the nature of the rules, as a guarantee of good governance (see specific analysis on 'Role and functioning of Boards').

“Rules provide structure, facilitate relationships, and set limits. Women have the impression that rules are constantly broken by an informal logic of 'power over' and not 'power for'. They have long suffered from this feeling, and that probably explains, in part, why they are more interested in putting more rules in place. The rules allow for formalism and transparency”, M. Dubouloy.

"Ethics and the law are two constraints on the exercise of power that I am subjected to. Another dimension that stands out for me lies in the general interest and the balance of powers at the heart of the Board... The rules at the heart of the company are essential and necessary for proper functioning, fortransparency, for longevity”, S. Lochmann.

"Rules are necessary guidelines in all aspects of community life. We need them in order to determine the fields of individual autonomy. So this is an area of freedom that allows the use of individual intelligence. It is important to define rules, and to communicate them. They must evolve over time: they are not set in stone”, N. Mesny.

"Rules are essential. I am particularly attached to implicit rules such as honesty and loyalty”, A. Arcier.

"The role of rules in a company is essential. Without precise rules, an organisation does not have the visibility and security that individuals require in order to adhere to (and progress towards) common goals. I am very attached to those rules related to equality, justice and generosity in the sharing of results”, A. Bricard.

"The main challenge of a manager (and team) is to measure their decisions in terms of ethical criteria”, S. Paix. 


\section{QUESTION : DO WOMEN FEEL PARTICULARLY ATTACHED TO RULES AND ETHICAL CONDUCT ? \\ (Sense of fairness, morality, sense of protection for rules that protect against unfairness or arbitrary decision-making)}

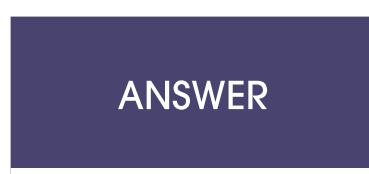

TOTAL 49

FRANCE 26

ABROAD 23
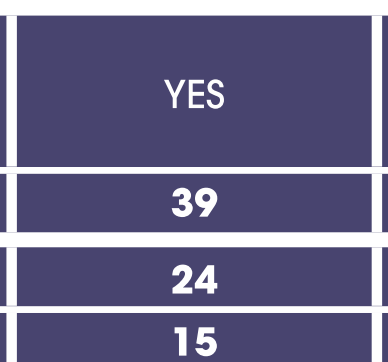

15

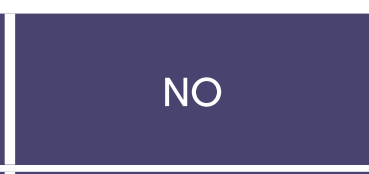

\begin{tabular}{|l|}
\hline 2 \\
2 \\
0
\end{tabular}

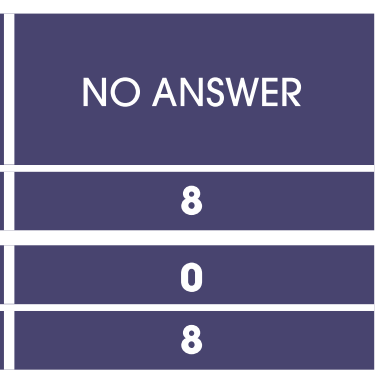

Source: Study “Women and Power”, Viviane de Beaufort, October 2012.

A Responsibilityto change the way Boards function.

The majority of women who spoke in the study "Women and Power"(De Beaufort, 2012) emphasised the need to change certain practices in the way that Boards function:

- Change aspects of governance: the current approach is too financial, not operational enough

- A systematic lack on the Board's Agenda: HR policy and aspects (including succession planning); technical and technological skills.

- Ensure the sustainability of the business and not just the income of Directors!

- The issue of remuneration is important. It must be gauged against strict and arduous quantifiable performance criteria. It must be justified, as this is important for social cohesion.

- The advice must be assessed more frequently, with longer and more in-depths reviews, in order to improve the functioning of the Boards. The magnitude of the current crisis relates back to core values: quality of management, composition and functioning of Boards, and 'increased role of the pilot operating the aircraft'.

"I just joined the Board of 'Lagardère', my project behind this commitment is to be useful, to make a contribution to the task ofbringing change. Women have the appetite for societal issues (CSR, sustainable development, NGOs, civil society, gender equality...)”, H. Molinari. 
(Power to do something, accountability, commitment to the public interest, courage to decide)

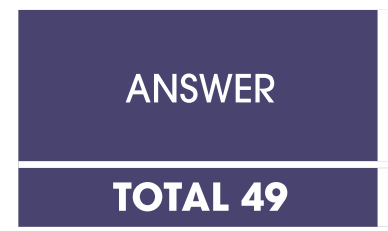

FRANCE 26 ABROAD 23
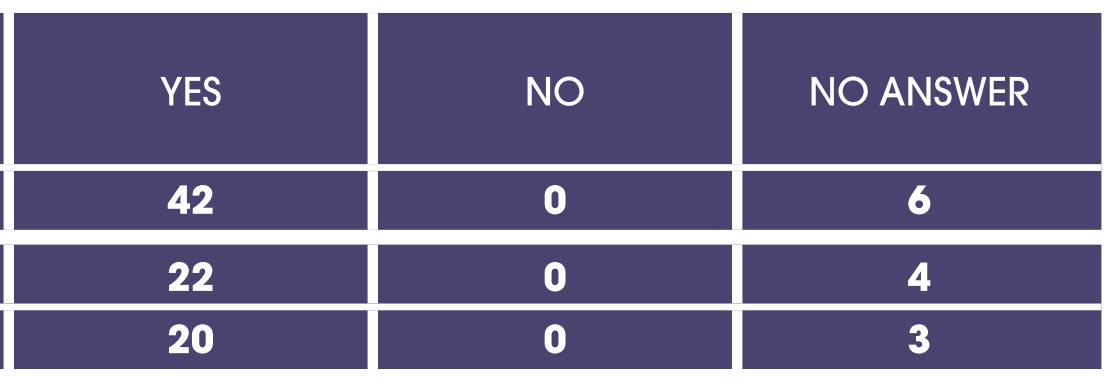

Source: Study “Women and Power”, Viviane de Beaufort, October 2012.

\section{An idealised vision of aDirectorship}

Within Boards, power games between the managers and those that supervise them are complex. The independence of aBoard member, a key requirement prescribed by all Governance Codes ${ }^{6}$, clashes with the manager's desire for power. Yet,within Boards, it has been confirmed that Board Members are more diligent and competent in preparingmeetings and asking questions, and will eventually oppose behaviour that they consider non-compliant with their beliefs (Woolley, Chabris, Pentland, Hashmi and Malone, 2010). In summary, they have the courage to seek to influence the manager or team in order to improve the functioning and decision-making of the board. A vast majority of the interviewees from the "Women and Power" study(De Beaufort, 2012)spoke about their conception of theprerequisite qualities of a Board member:

\section{The key roles of non-Executive Directors:}

- Know the field/sector/industry

- Participate in specialised committees including the Audit Committee

- Provide specific expertise

- Have the ability to understand complex issues by making them understandable and enforceable

- Monitor and measure the implementation of strategy

As well as:

- Manage the business strategy and the coaching the management team

- Integrate the "long term", “vision”, “future” dimensions.

- Participate in the construction of what makes the company "preferred" in the eyes of the public is part of the mission of aDirector: Sustainable Development

- Challenge the Business Model of the Company

- Reveal new business models or territories 
In this exercise, such women wishing to take hold of their roleas 'new arrivals', motivated by their idealised conception of Boards, may sometimes have problems positioning themselves, since their behaviour disturbs the status quo. They will have a choice to resist or to conform. Their impact may be questioned, regardlessof their skills.

\section{A need for Diversity}

Diversity and 'added value'.

Diversity is clearly perceived as bring added value to companies, based on the responses of the interviewees of the "Women and Power" study(De Beaufort, 2012):

"It is best when Directors are very different. It is the range of combined skills and diversity of profiles that create the wealth of a Board of Directors ",I. Seillier.

"The challenge is to transform the Boards, so that they are: more diverse, more feminine, more international, younger, and that the profiles of the members compliment each other", $\mathrm{H}$. Molinari.

"Companies must be able to further diversify and internationalise their Board of Directors by consequently integrating women”, S. Lochmann.

"We must ensure that a Board of Directors is composed of different personalities in order to create a coherent whole that functions at its best. It is the result of the juxtaposition of temperaments and personalities that create a good Board”,Anonymous. 
"Feminine" qualities brought to the 'Director's table' may change the game.

Women who have recently been nominated for Directorships often bring fresh eyes, with an impartial perception of past decision and actions.

QUESTION : DO WOMEN HAVE PARTICULAR/SPECIFIC QUALITIES OR ATTRIBUTES?
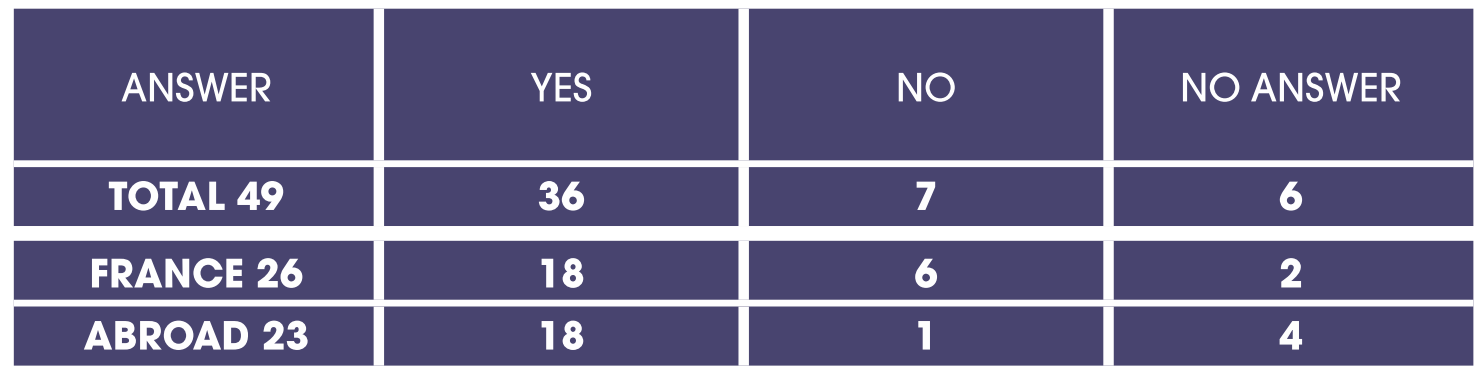

Source: Study “Women and Power”, Viviane de Beaufort, October 2012.

An overwhelming majority of the women interviewed(De Beaufort, 2012)freely evoked feminine characteristics that they considerto be qualities: listening and empathy, emotional intelligence, intellectual honesty (ability to recognise mistakes of judgement). The challenge is therefore to resist the peer pressure of the dominant model in order to preserve and further develop the unique attributes.

N. Ball:Greater ability to listen, capability to more completely analyse subjects, and a middle of the road perspective.

B. Dalibard: A perception of the concrete, motivated by a common interest, daring enough to ask questions (of HR specifically), good at keeping their ego out of the way.

D. Elyaacoubi: More intuitive.

D. Ernotte-Cunci: More collective, using less unverifiable assertions, more courageous, more able to think freely. 
S. Ouziel: Less of a political reflex. Women do things for the company and not for appearances. Women have a real concern about making things move forward, they are less into politics and their personal positioning. They bring more objectivity and sense of the practical. Women are idealists and impassioned...Women are less dogmatic.

A. Arcier: Capable of cooperation and compromise, better ability to anticipate by listening and intuition, better sense of the concrete.

A. Bricard: Women have by necessity a better ability to listen since our social culture has taught them to "listen" to the man (the father, the husband, the son). They have a greater capability to challenge their perceptions as they have aless-developed ego. And finally, since they place the general interest above their own, they are less career-oriented, less calculating, they don't hesitate to tell the truth even if it may be upsetting.

"It is necessary to bring some diversity to Boards. Independent Directors bring meaning, a broader vision, more objectivity, and complementary expertise. Women are very sensitive to many ethical considerations and their sense of teamwork facilitates the operation of a Boardas a "team." Diversity is the guarantor of new ideas. Female Company managers, though the responsibilities exercised within their own business, can bringadded value: they know about the functioning of Boards, have knowledge of the market, knowledge of international considerations, an/or technical knowledge. They are also used to developing and discussing strategies, they do not hesitate to contribute their vision”,M-C Oghly ${ }^{7}$. 


\section{CONCLUSION:THE ‘ADDED VALUE’ OF A MIXED LEADERSHIP MODEL}

The normalisation of women in positions of power, the current evolution in our society with the incursion of diversity andthe development of new models are changing the game.The personal motivation of women and the feminine 'way of thinking' seem to be, rather than a handicap, better adapted to the more flexible management model required by current evolutions: the engine of power gives way in favour of responsibility, and that value of example takes the baton from speech. A more emotional way of thinking is more in step with a humanist leadership approach, which integrates rationality and intuition, and measured taking of risks. The ideal manager of either gender must henceforth be able to blend the male skills (charisma, leadership, impartiality, decision making capability...) with the female (rationality, empathy, listening, organization, knowledge...):

"Women practice a management of convictions, more than a management of authority”,according to Anne-Marie Idrac (interviewed in Gilbert, 2012).

"In more advanced companies the moment is approaching where men and women working together will open new trajectories and a different creation of values”, Marie Boy(interviewed in Gilbert, 2012).

"Instead of forcing women to adopt male behaviour in order to accede to power, why not encourage men to develop more feminine types of behaviour? This time is no longer for duelling, but rather for duality”, RafikSmati(Bramly, Carminati-Rabasse et al, 2012).

"To achieve good things you need people with different opinions, having different experiences, and minds but sharing the same goal - without diversity, you only reach incremental goods”, BengtJarrehult ${ }^{8}$. 
Ways of decision-making are becoming more transverse, more collective and women seem particularly comfortable with these changes:

"A woman sometimes has a greater capacity to surround herself with a team that will be able to talk to her, to tell her what is really going on; decisions made by women are sometimes more collegiate”,D.Ernotte-Cunci(De Beaufort, 2012).

"Men...sometimes have the feeling that only authoritarian models can work in management. My philosophy is that I'm not here to yell at people”, D. Ernotte-Cunci(De Beaufort, 2012). Power isolates only "if it is wielded with authority. It is important to exercise power with an approach of 'soft influence': constantly confront the ideas of others, put yourself at the same level as the others. It should be free speech. Everyone is an actor of the project. Thus the power is stronger, visible, effective ... There are still too many conservative attitudes...There is an obvious complementarity between men and women, allowing them to produce more profound changes, gently”, H. Molinari(De Beaufort, 2012).

"A certain conformism prevails within Boards. Being the voice of innovation is more or less well perceived. We must empower Boards and succeed in creating a real dynamic within Boards. In general, the corporate world encourages conformism rather than courage. The search for greater diversity must come down to a concern for greater business and economic efficiency, and not a simple conformism”, S. Ouziel(De Beaufort, 2012).

Could a mixed leadership style (one that incorporates and embraces "female" qualities) be a way to limit the employee disengagement trend? 
The latest research by Aon Hewitt, the global leader in Human Resource solutions, shows that in 2011 , only $52 \%$ of employees in Europe, and $58 \%$ globally, are engaged ${ }^{9}$ by their work. According to Aon Hewitt (2012): "striving to maintain a higher level of employee engagement is a key factor for longer-term business performance and better positioning when market conditions become favourable."Against the current economic backdrop and the fact that recruiting costs run at approximately 1.5 times annual salary(MSW Research and Dale Carnegie Training, 2012), it is apparent that it has become more important than ever for employers to develop and maintain highly engaged employees.

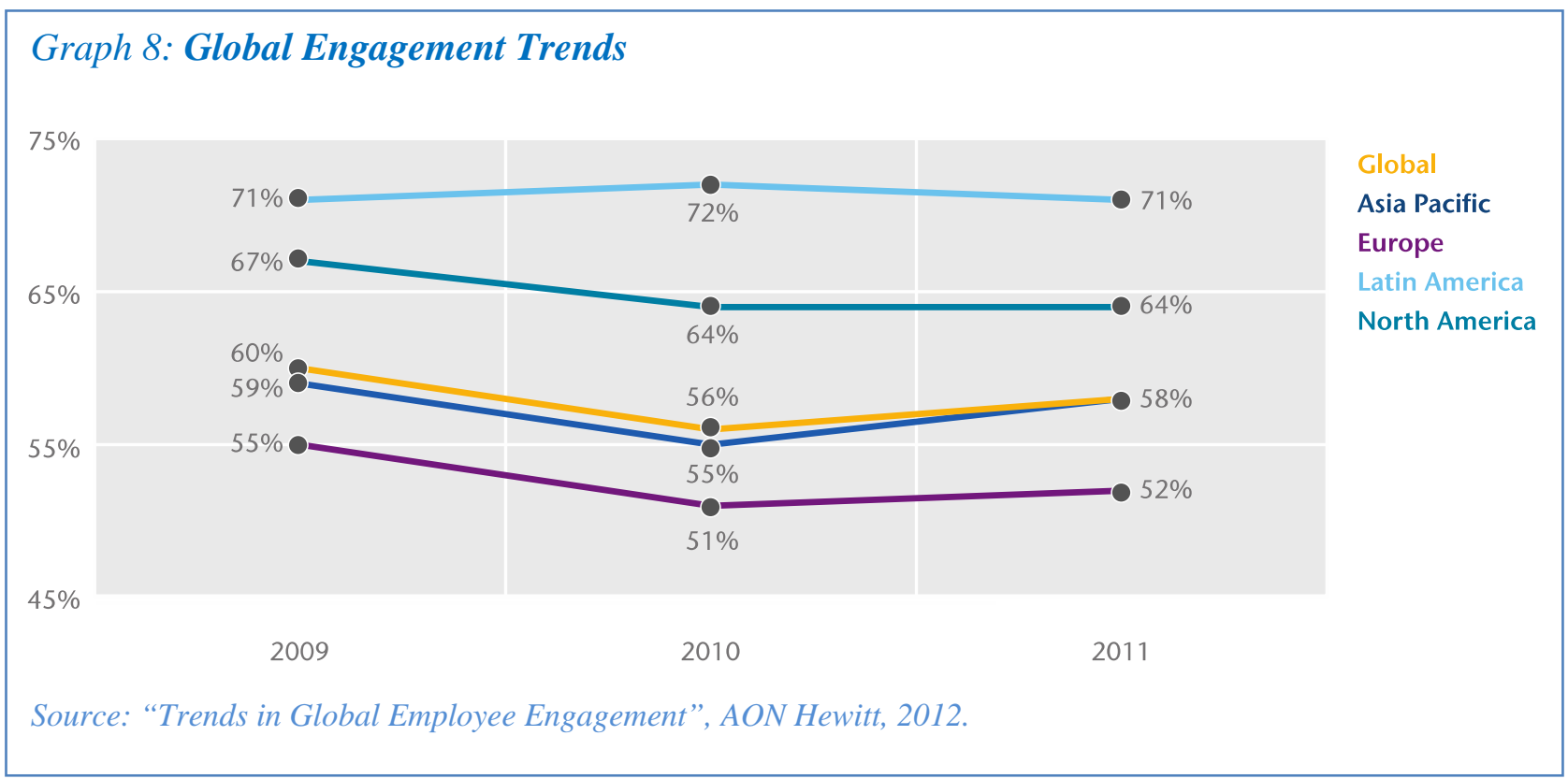

Forbeslooked at "what qualities are more useful in fostering engaged, productive employees... in building positive manager-employee relationships?" The author, Victor Lipman(2013) concedes that "almost without exception the most effective managers and executives I knew (in addition of course to possessing technical proficiency) shared five - for lack of a better term - softercharacteristics” including:

\section{- Being a good listener}

- Showing perception to the more subtle issues and motivations of other employees

- Good and open communicators who are approachable and available

- Having a calm demeanour

- Having a general concern for the well being of the colleagues, and who can be trusted to keep their word

Women tend to act more like a coach than an individual player, being more concerned with the glory of the team over personal goal scoring. Furthermore, women are more inclined have better- 
developed 'soft' skills from the characteristics list cited, including relational and emotional intelligence, holistic perspective, inclusion, empathy and intuition, as outlined in this article. These skills are the skills required in facilitating a superior sensitivity to issues that can create low job satisfaction, and ultimately help to reverse the trend of high employee disengagement.

\section{ENDNOTES}

\footnotetext{
${ }^{1}$ For a discussion of the recent improvements to the UK Corporate Governance Code with respect to improving Gender Diversity on Boards, refer to section on 'The recent efforts of the United Kingdom encouraging the market to regulate the problem'.

${ }^{2}$ Sheryl Sandberg is the COO of Facebook, and the author of the book 'Lean In' (2013). She made this statement during her speech at the Stanford Clayman Institute for Gender Research in April 2013. http://www.youtube.com/watch?v=f9-d FRjwYM
}

${ }^{3}$ De Beaufort, V. “Women and Power: Taboo, or new Corporate Governance Model? ”, ESSEC and Boyden (joint publication), September 2012.

As part of the qualitative research for the "Women and Power" study, 49 women provided interviews that were very detailed in content. The complete in-extenso version of those interviews has been published along side the "Women and Power" study: https://sites.google.com/a/essec.edu/vivianede-beaufort/engagement-women/leadership-au-feminin.However, it was always intended (and stated in the original publication) that these interviews would be subsequently analysed under the Corporate Governance microscope in order to highlight the fact that current and potential female candidates share a rigorous vision of the functioning of Boards and therefore demand a new model of governance. As such, the content that was exploited and cited in this article arenot the same as those used to support the conclusions made in the previous article, which focused purely on women and their interaction with power. This article, as the title "Women and Corporate Governance: towards a new model" suggests, focuses on the relevant comments made by the interviewees with respect to specific questions of corporate governance and the functioning of Boards.

Interviewed women that are cited in this article include:

- $\quad$ Isla Ramos Chavez, Executive Director of Europe, Middle East \& Africa Business Transformation at Lenovo.

- StéphaniePaix, President of the Board of la Caissed'Epargne Rhône-Alpes (Groupe BPCE). Board Member of Natixis and of CréditFoncier de France. 
- $\quad$ Sylvie Ouziel, CEO of Allianz, Managed Operations \& Services SE (AMOS SE).

- DelphineErnotte-Cunci, Deputy CEO of France Telecom- Orange, Senior Executive Vice President of Orange France, Board Member of Suez Environnement.

- Sabine Lochmann, General Manager of Strategic and Governmental Affairs at Johnson \& Johnson Medical Company, President of the association 'Avenir FemmesSante'.

- Natalie Balla, CEO of La Redoute (Groupe Redcats).

- DiaaElyaacoubi, CEO of StreamcoreSystem France. Board Member of Ingenico France. AgnèsBricard, Founder and President of the Accounting Firm Bricard, Lacroix\&Associés, President of French Public Accountants' professional organisation, Vice-President of 'Club Action de Femmes'.

- Emmanuelle Gagliardi, Associate Director of Connecting Women, Director of the magazine L/ONTOP.

- Isabelle de Kerviler, Partner at CailliauDedouit and Associates, Financial Expert for The Court of Cassation (The Highest Court in France), Counsellor for Paris (1983-2001), Member of the 'Economic, Social and Environmental Council' of France (CESE), Vice-President of the 'Economic Activities' department.

- ValérieRocoplan, Founder and Director of Talentis(Executive Management CoachingInternational).

- Barbara Dalibard, Managing Director of SNCFVoyages. BoardMember of Wolters KluwerNV, CompagnieGénérale desÉtablissementsMichelin SCA,GlobeCastHolding SA, et Michelin SA.

- $\quad$ Nathalie Mesny, Mangaging Director of OxybulEveil\&Jeux.

- Anne-Sophie FauvetMulliez, Board Member of Pimkie. Member of the Decathlon Foundation, Member of the Managing Committee of AFM.

- Colette Lewiner, Chairwomen of TDF, Energy Advisor to Capgemini. Board Member of Bouygues, Colas, Eurotunnel, Lafarge, Nexans, and TGS-Nopec Geophysical Company.

- Pascale Sourisse, Senior Vice-President for the Land and Joint systems division at Thales Group. Board Member of Telecom ParisTech School, Vinci, Renault and DCNS.

- Sophie Auconie, Member of the European Parliament for the French constituency "Massif-Central- Centre", Co- founder and Chair of the Association "Femmes au Centre".

- MaryseDubouloy, Associate Professor in the Management Department at ESSEC Business School, Consultant/Coach at RéseauPluridis. She helped in guiding the development of the Interview Question for the study "Women and Power" by Viviane de Beaufort, and was also interviewed in her capacity as an expert psycho-clinician.

- Agnes Arcier, Director of ADETEF Bercy (The French international technical assistance agency of the Ministries for the Economy, Budget and Sustainable Development), as well as founder of the French Female Board Members Association "Administration Moderne”. 
- Hélène Molinari, Deputy Managing Director of the MEDEF (Movement of the Enterprises of France, which is the largest union of employers in France). Supervisory board Member of LagardèreGroupe.

- Isabelle Seillier, Chairman of JP Morgan France. Member of EMEA Executive Commitee and EMEA IB inclusive Leadership Council (Diversity Council), Board Member of Europlace Paris and of AFB, Danone and Club Méditerranée.

${ }^{4}$ Women Be European Board Ready-ESSEC is a high level executive programme specifically designed for women, preparing to become a member of a Board, or wishing to improve their contribution in an existing mandate or position. http://executiveeducation.essec.edu/programs/programs/formation/women-be-european-board-ready.html

${ }^{5}$ Note 4. Established in March 2011, this Executive programme combines the teachings on the fundamentals of what is modern and sustainable Corporate Governance and specific coaching on the "GENDER" dimension: group coaching, testimonials, support networks, meetings of executive search firms, Collective research for mandates, training in social networking. For video of testimonials from women from the $2^{\text {nd }}$ Session (English translation in the comments section): http://www.youtube.com/watch?v=JnE8zEEINO8

${ }^{6}$ For example, The European 'COMMISSION RECOMMENDATION on the role of non-executive or supervisory directors of listed companies and on the committees of the (supervisory) board', Commission Recommendation 2005/162/EC of 15 February 2005 (OJ L 52, 25.2.2005, p. 5163).http://eur-lex.europa.eu/LexUriServ/LexUriServ.do?uri=OJ:L:2005:052:0051:0063:EN:PDF

${ }^{7}$ Ms Oghly was interviewed especially for this study. She is the President of the MEDEF, Ile de France (Movement of the Enterprises of France, which is the largest union of employers in France)and President of the French branch of Femmes Chefs d'Entreprises (Association of Women Entrepreneurs), as well as the Vice-President of the global branch (World Association of Women Entrepreneurs).

${ }^{8}$ BengtJarrehult is the 'Director of Innovation' at SCA AB India (45000 employees, 60 countries). Quote taken from a LinkedIn forum discussion.

${ }^{9}$ Aon Hewitt defines engagement "as the state of emotional and intellectual involvement that motivates employees to do their best work."

\section{REFERENCES}


AON Hewitt.“Trends in Global Employee Engagement”, AON Corporation, 2012.http://www.aon.com/attachments/human-capitalconsulting/2012 TrendsInGlobalEngagement_Final_v11.pdf

Arcier, A. "Le quotient féminin de l'entreprise, question de dirigeants", Editions Village mondial, 2002.

Bertin-Mourot, B \&Laval, C. "Repenser l'équilibre hommes/femmes dans la ressource managériale et dirigeante", Les Echos Etudes, 2006.

Bramly, S\&Carminati-Rabasse, A et al. "Pouvoirs(e)s, les nouveaux équilibres femmeshommes",Eyrolles, May 2012.

Bournois, F, Duval-Hamel, J, Roussillon, S, Scaringella, J.L, de La Tour d'Artaise, T et al. "Comités Exécutifs - Voyage au coeur de la dirigeance”, Eyrolles, 2007.

Buffett, W. "Warren Buffett is bullish...on women!”, Fortune Magazine, 20 May 2013. http://money.cnn.com/2013/05/02/leadership/warren-buffett-women.pr.fortune/index.html

Capitalcom. "7ème BAROMÈTRE ANNUEL CAPITALCOM SUR LA MIXITÉ - De plus en plus d'entreprises s'engagent : la fixation d'objectifs chiffrés a doublé en 5 ans", Press Release, March 2012, http://www.capitalcom.fr/Documents/Etude\%20Femmes\%202012.pdf

Capitalcom. "7ème BAROMÈTRE ANNUEL CAPITALCOM SUR LA MIXITÉ DANS LES CONSEILS D'ADMINISTRATION DU CAC 40 - Le lady boom s'essoufflerait-il déjà ?” Press Release, May 2012, http://www.capitalcom.fr/Documents/CP\%20Femmes\%20AG\%202012.pdf

Capitalcom. "8ème BAROMÈTRE ANNUEL CAPITALCOM SUR LA MIXITÉ - D’une affaire de femmes à un enjeu de performance...”, Press Release, June 2013.

http://www.capitalcom.fr/Documents/CP 8ème\%20BAROMTRE\%20ANNUEL\%20CAPITALCO M\%20SUR\%20LA\%20MIXIT_2013.pdf

Catalyst, "The Bottom Line: Connecting Corporate Performance and Gender Diversity", Catalyst, 2004.

Catalyst, "The Bottom Line: Corporate Performance and Women's Representation on Boards", 2007

Caye, J-M, Teichmann, C,Strack, R, Haen, P, Bird, S \&Frick, G. "Hard-Wiring Diversity into Your Business", BCG Perspectives, 2011. 
Charlotte, "Stéréotypes et plafond de verre”, Blog 'Jeunes Professionnelles', 17/12/2012, http://jeunesprofessionnelles.com/2012/12/stereotypes-et-plafond-de-verre/

Chevalier, C \&Khadir, S. “Les stéréotypes sur le genre” IMS-Entreprendre pour la Cité, May 2012.

Curtis, M, Schmid, C\&Struber, M. "Gender Diversity and Corporate Performance”, Credit Suisse AG (Research Institute), August 2012.

De Beaufort, V. "Women and Power: Taboo, or new Corporate Governance Model? ", ESSEC, September 2012.

Dugas, L. "Grandir comme dirigeant", in 'Comités Exécutifs - Voyage au Cœur de la dirigeance', Eyrolles, 2007.

Dyrchs, S and Strack, R. "Shattering the Glass Ceiling: An analytical approach to Advancing Women into Leadership Roles”, Boston Consulting Group (BCG), August 2012.

EgonZehnderInernational. "Board Diversity: From Problem to solutions", The FOCUS magazine, November 2012.

Enriquez, E \&de Brouwer, D. "Les jeux du pouvoir et du désir dans l'entreprise" (Power and desireGames in the Company), Desclée de Brouwer, 1997.

Europa, "The European 'COMMISSION RECOMMENDATION on the role of non-executive or supervisory directors of listed companies and on the committees of the (supervisory) board"', Commission Recommendation 2005/162/EC of 15 February 2005 (OJ L 52, 25.2.2005, p. 5163).http://eur-lex.europa.eu/LexUriServ/LexUriServ.do?uri=OJ:L:2005:052:0051:0063:EN:PDF

Europa, "Report on equality between men and women", Report from the Commission to the Council, the European Parliament, the European Economic and Social Committee and the Committee of the Regions.77 final, 2009.http://eurlex.europa.eu/LexUriServ/LexUriServ.do?uri=CELEX:52009DC0077:EN:NOT

Europa, "Strategy for the inequality between women and women-2010-2015", Communication of the European Commission, 491 final, 2010.http://eurlex.europa.eu/LexUriServ/LexUriServ.do?uri=CELEX:52010DC0491:EN:NOT

Europa, "The Gender balance in business leadership", Working document of the European Commission SEC 246 final, 2011.

http://ec.europa.eu/employment social/publications/2008/ke8108186 fr.pdf 
French Parliament, "Loi sur la représentation équilibrée des femmes et des hommes dans les conseils d'administration et de surveillance (Act on the balanced representation of women and men on Boards of Directors)”, Law number 2011-103 of 27 January 2011.

Gilbert, S. "Femmes d'Altitude”, Les Belles Lettre, March 2012.

Gladman, K\& Lamb, M. “GMI Ratings’ 2013 Women on Boards Survey”, GMI Ratings, April 2013.

Heidrick\& Struggles. “Challenging board performance - European Corporate Governance Report”, 01101PBTSMI59, p.40, 2011.

Landel, M, “Rapport annuel de la diversité”,Sodexo, 2009.

Lipman, V. "Why Are So Many Employees Disengaged?”, FORBES, “Leadership" Channel, 18 January 2013, http://www.forbes.com/sites/victorlipman/2013/01/18/why-are-so-many-employeesdisengaged/

Lunghi, C. “Et si les Femmes réinventaient le travail”, Editions L’Organisation, 2001, p.201.

Lord Davies of Abersoch. "Women on boards", UK Department for Business, Innovation \& Skills, March 2012.http://www.bis.gov.uk//assets/biscore/business-law/docs/w/12-p135-women-on-boards2012.pdf

Lord Davies of Abersoch. "Women on boards", UK Department for Business, Innovation \& Skills, April

2013.https://www.gov.uk/government/uploads/system/uploads/attachment_data/file/182602/bis-13p135-women-on-boards-2013.pdf

McKinsey and Company, "Women Matter", McKinsey and Company Studies: 2007, 2008, 2009, 2010, 2012.

MSW Research and Dale Carnegie Training, "What Drives Employee Engagement and Why It Matters", October 2012, http://www.dalecarnegie.com/imap/white_papers/employee engagement_white paper/

Persche, A \& Perdue, J. "Women and the Paradox of Power: 8 Keys for Transforming Business Culture", Germane Consulting/Braithwaite Innovation Group, 2011.

Rocoplan, V \&Vanbremeersch, C. “Oser être la chef”, Chapter 12: developyourpoliticalsense, Leducseditions, January 2011. 
Rocoplan, V. "Les Stéréotypes”, Elles réussissent (la newsletter de Valérie Rocoplan), Numéro 4, Juillet 2012.

Sarfati, A-C\&Gattegno, H. "Femmes au pouvoir ; récits et confidences”, Stock, 10 October 2007.

Sealy, R\&Vinnicombe, S(OBE). "The Female FTSE Board Report 2012”, Cranfield International Centre for Women Leaders (Cranfield University), 2012.

http://www.som.cranfield.ac.uk/som/dinamic-content/research/documents/2012femalftse.pdf

Sealy, R\&Vinnicombe, S(OBE). "The Female FTSE Board Report 2013”, Cranfield International Centre for Women Leaders (Cranfield University), 2013.

http://www.som.cranfield.ac.uk/som/dinamic-

content/media/Research/Research\%20Centres/CICWL/FTSEReport2013.pdf

Stanford Clayman Institute for Gender Research. "Sheryl Sandberg at Stanford 4/2/13", video of interview with Sheryl Sandberg in April 2013: http://www.youtube.com/watch?v=f9-d FRjwYM

Stone, P, Cornet, A \&Cusumano, C.“Les quotas”, L’encyclopédie des diversités, Chapter 28, 2012.

Woolley, Chabris, Pentland, Hashmi and Malone. "Evidence for a Collective Intelligence Factor in the Performance of Human Groups", Sciencexpress, 30 septembre 2010.

Zenger, J \&Folkman, J. “A Study in Leadership: Women do it Better than Men”, Zenger Folkman, 2012, http://www.zfco.com/media/articles/ZFCo.WP.WomenBetterThanMen.033012.pdf

Zenger, J \&Folkman, J. “Are Women Better Leaders than Men?”, HBR Blog Network, 15/03/2012: http://blogs.hbr.org/cs/2012/03/a_study_in_leadership_women_do.html

\section{COMPLEMENTARY REFERENCES:}

Adams \&Ferreira."Women in the boardroom and their impact on governance and performance", Journal of Financial Economics 94, 2009. 
Analysis Note Smith.“Gender Equality and Recession”, EGGE, 2009.

De Beaufort, V. "Managerial Diversity In The European Union - the social and economic stakes", DR Ceressec-Academic partnership with Women's forum, 2007.

De Beaufort, V in collaboration withJaquet, R. "Quelles pistes pour faire progresser la place des femmes dans l'économie?",Women Be EuropeanBoardReady, April 2011.

De Beaufort, V \&Khayat, M. "Femmes dans les conseils d'administration en France, Quelques considérations sur leur intégration et leur visibilité”, Research Center, ESSEC WorkingPaper 1202,February 2012.

De Beaufort, V, Lambert, C \&WomenOnBoards of EPWN.“Le Guide de l'Administrateur(E)”, March 2012.

Dubouloy, M. "Women on boards in French companies between the desire of new politics and the reality of old power", London, December 2011.

EuropeanPWN, "Fourth Bi-annual EuropeanPWNBoardWomen Monitor 2010”, Indicators drawn-up by the association in 2010 .

EPWN Women@work:

"Women on boards-Moving Beyond Tokenism",Women@work N².

"Mentoring-a powerful -Tool for Women",Women@Work N7.

"Women on boards, moving mountains",Women@Work No8.

“Réseaux, le nouveau fil d'Ariane”,Women@Work N¹1.

Finnish Business and Policy Forum.“Female Leadership and Firm Profitability”, EVA, 2007.

Fitoussi, M. “Femmes au pouvoir, femmes de pouvoir”, éditions Hugo \& Compagnie, 2007.

Graduates of the GEF (GrandesEcoles au Féminin) Network."L'Ambition au Féminin”, February 2005.

Gresy, B \&Dole, P. "Rapport sur l'égal accès des femmes et des hommes aux responsabilités professionnelles et familiales dans le monde du travail”, Inspection générale des Affaires sociales, June 2011.

Héritier, F. "Hommes, femmes: la construction de la différence”, éditions L Pommier, 2010. 
IPSOS \&GEF (Grandes Ecoles au Féminin). "Le parcours professionnel des diplômé(e)s de grandes écoles" - Regards croisés hommes/femmes, February 2007.

Ivey, R. "Critical Mass on Corporate Boards: Why three or more women enhance governance", School of business, University Western Ontario, 2006.

Kimmel, M. “The Gendered society”, New York, Oxford Press University, 2004.

Knowledge@Wharton, "Masculine Norms': Why Working Women Find It Hard to Reach the Top", in, 3 August 2011.

Kotiranta, A,Kovalainen, A\&Rouvinen, P. "Female Leadership and firm profitability”, 2003.

Laufer, J \&Pochic, S in Karvar, A \&Rouban, L (dir.).“Carrières au féminin et au masculin, Les cadres au travail. Les nouvelles règles du jeu”, Paris, La découverte, p. 147-168, 2004.

Laufer, J. "Femmes et Carrières : la question du plafond de verre", RFG, 2004.

Levant, R.F.\&Richmond, K. "A Review of Research on Masculinity Ideologies Using the Male Role Norms Inventory”, The Journal of Men’s Studies vol. 15, p. 130-146, March 2007.

Molinier. "Le continent noir de la féminité : sexualité et/ou travail ?”, Cliniques méditerranéennes, 2002.

Observatoire de la Responsabilité Sociétale des Entreprises (ORSE). "L'accès des femmes aux postes de responsabilité dans l'entreprise", 2004.

Observatoire de la Responsabilité Sociétale des Entreprises (ORSE). “L'accès et la représentation des femmes dans les organes de gouvernance d'entreprise”, Institut Français des Administrateurs (IFA), EPWN- Paris, September 2009.

Pigeyre, F, Bouffartigue, P (dir) \&Grelon, A. "Femmes dirigeantes : les chemins du pouvoir”, 2001.

Pollack, W."Real boys”, New York, Henry Holt and Company, 1999.

The International Organization Network. "Planning Tomorrow's Boardroom: Making room for Women", March 2009. 
ESSEC Business School Avenue Bernard Hirsch BP 50105

95021 Cergy-Pontoise Cedex France

Tél. +33(0)134433000

$\mathrm{Fax}+33(0) 134433001$

www.essec.fr

\section{ESSEC Executive Education} CNIT BP 230

92053 Paris-La Défense France

Tél. + $33(0) 146924900$

Fax +33 (0)1 46924990

http://formation.essec.fr

ESSEC Business School

Singapore Campus

100 Victoria Street

National Library Building \# 13-02

Singapore 188064

essecasia@essec.fr

Tél. +6568849780

Fax +6568849781

www.essec.edu

Informations

Alison Bougi

+33 (0)134433358

bougi@essec.fr

www.essec.fr

research.center@essec.fr

ISSN 1291-9616 